\title{
sciendo
}

DOI: 10.2478/orga-2019-0011

\section{Quality Management Evolution from the Past to Present: Challenges for Tomorrow}

\author{
Syaiful Rizal HAMID ${ }^{1,2}$, Saifuddin ISA ${ }^{2}$, Boon Cheong CHEW ${ }^{2}$ and \\ Abdullah ALTUN ${ }^{3}$
}

\begin{abstract}
${ }^{1}$ Faculty of Business Administration, Gebze Technical University, 41400 Gebze, Turkey, rizal@gtu.edu.tr
${ }^{2}$ Faculty of Technology Management and Technopreneurship, Universiti Teknikal Malaysia Melaka, Hang Tuah Jaya, Durian Tunggal, 76100 Melaka, Malaysia, syaiful@utem.edu.my
\end{abstract}

${ }^{3}$ Enterprise Resource Management, Financial Monitoring Department, Tubitak Bilgem, 41470, Gebze, Kocaeli, Turkey.

Background and purpose: The quality management field has been studied for more than 100 years dating back to the early 1900s when Fredrick W. Taylor is known as the father of Scientific Management, stressed the importance of quality inspection. This paper describes how quality management field has developed and evolved to date, particularly by tracking its focus over time.

Design/Methodology/Approach: A systematic approach to literature review was adapted in this research. Identifying the gurus and the scholars in this field makes it possible for the researchers to review their works, which are, mainly, in the form of books and journal articles. Process in getting literature review that has been conducted include quality management in general, as well as 'evolution of quality management' and 'development of quality management' respectively in capturing the field of quality management and thus, illustrating how the quality management field has evolved over the time.

Results: It appears that quality management literature have evolved through time, and as they evolved, the principles, systems, tools and techniques have changed. As a result of the study, this paper also provides the synthesis of quality management literature over time according to the key focus and gives a new perspective for the further research.

Conclusions: The historical review allows the researchers to establish the pattern of quality - the 'focus, principles, systems, and tools and techniques' over time. Our observations have confirmed that as the focus has changed, the principles have also changed and as the principles have changed, the systems, tools and techniques also have changed in quality management field.

Keywords: Quality Management; focus; principles; systems; and tools and techniques.

\section{Introduction}

The quality management field has been studied for more than 100 years dating back to the early 1900 s when Fredrick W. Taylor known as the father of Scientific Management, stressed the important of quality inspection (Foster,
2001, p. 44; Garvin, 1988, p. 5). According to Feigenbaum (1961), quality does not mean "best" but "best for the customer use and selling price". While Crosby (1984) deems that quality has to be defined as conformance to requirements. In turn, Juran (1988) points out that quality is "fitness for use", recognises that a product or service must be produced with the customers' need in mind.

Received: September 23, 2018; revised: February 18, 2019; accepted: June 10, 2019 
"Freedom from defects" and "fitness for use or purpose". Further, Drucker (1989) claims that quality in a product or service is not what the supplier put in. It is what the customer gets out and is willing to pay for. Likewise, Deming (1993) states that quality means a predictable degree of uniformity, dependability at low cost and suited to the market. As this is seconded by several literature studies which proposed the importance of a product or service must be produced with the customers' need context, such as (J. J. Dahlgaard, Kristensen, \& Kanji, 2002; Foster, 2001; Price, 1990; Richardson, 1997; Slack, Chambers, Johnston, \& Betts, 2006; Stamatis, 1996).

Looking from a bigger picture, quality management has been defined as "philosophy or an approach to management" made up of a "set of mutually reinforcing principles, each of which is supported by a set of practices and techniques" (Dean \& Bowen, 1994). Thus, (Godfrey, Dale, Marchington, \& Wilkinson, 1997) point out that quality management is about all aspects of the overall management function that determine the quality policy objectives and responsibilities, and implement them by means such as quality planning, quality control, quality assurance and quality improvement within the quality system. Consistent with this (Sousa \& Voss, 2002) also highlight that quality management is a managerial philosophy or an approach made up of a set of mutually reinforcing principles, each of which is supported by a set of practices, tools and techniques for enduring effectiveness and efficiency with respect to the systems and its performance.

In general, it appears that there is agreement on the definitions of quality and quality management means although different authors use different terminology. Therefore, we would say that there seems to be no conflict or argument between the authors. It is believed that the patterns of quality management literature are influenced by the big gurus' thinking (i.e. Shewhart; Deming; Juran; Crosby, Feigenbaum and Ishikawa) which reflects the stream and direction of the quality movement as they are today. This is consistent with the works of Martinez et al. (1998) who further reinforced that the quality management movement can be tracked by looking at the Crosby, Deming, Feigenbaum, Ishikawa and Juran works', as they can be considered the most important gurus of the quality management field.

As such, a number of studies have focused on accessing the quality management approach, tools and techniques such as Total Quality Management (Belohav, 1993; Garrity, 1993; Hellsten \& Klefsjo, 2000; G. K. Kanji, 1990; Kano, 1993; Macdonald, 1995; Martinez-Lorente, Dewhurst, \& Dale, 1998; Milakovich, 1991; Powell, 1995; Taylor \& Pearson, 1994), Six Sigma (Eckes, 2005; Kuei \& Madu, 2003; Stamatis, 2003), and Lean Manufacturing (Hanna, 2007; Jayaram, Vickery, \& Droge, 2008; Kremer \& Fabrizio, 2005; Patty \& Denton, 2010; Womack, Jones, $\&$ Roos, 1990). In recent years, the focus of these studies was to assess the integration of quality management
(Pavel Castka \& Balzarova, 2008; Fernie \& Sparks, 2014; Mortimer \& Mortimer, 2015; Muzaimi, Chew, \& Hamid, 2017; Oaklan, 2014; Prajogo \& Sohal, 2006; Ross, 2017; Thai \& Jie, 2018; Yoon, Giirhan-Canli, \& Schwarz, 2006) in the context of supply chain, risk management, corporate social responsibility and operation management. Some other studies such as (Bititci, Garengo, Dorfler, \& Nudurupati, 2008; Burge, 2009; Giannakis, 2007; Hakes, 1999; G. Kanji, 2002) focused on assessing the quality management merely on the perspective of performance measurement matters. While, (Berger, 2007; Devadasan \& Goshteeswaran, 2005; Gunasekaran, 1999; Jin-Hai, 2003) focused on quality management in manufacturing industry (i.e. Agile manufacturing) and others such as (Chaniotakis \& Lymperopoulos, 2009; Kumar, Kee, \& Charles, 2010; Tan, Hamid, \& Chew, 2016; Zeithaml, Parasurarnan, \& Malhotra, 2002) highlighted the quality management link to service quality.

It indicates that the majority of studies have been conducted to measure or validate quality management agenda from customers' perspectives or managers' perspectives without much attention given to examining the concept of quality from the perspective of development and evolution of quality itself. In addition, examining the evolution and development perspectives has been recommended by previous studies, for example (Chiaromonte, 2004; Cho, Jung, \& Linderman, 2017; Cochran, 2007; S. M. Dahlgaard-Park, 2011; Freeman \& Louca, 2001; Martinez-Lorente et al., 1998; Schroeder, Linderman, \& Zhang, 2005; Wang \& Kleiner, 2005).

Thus, all of the above literature suggests that there is an ample amount of literature review on quality management, the majority of studies have been conducted to measure or eliciting the view of quality management from customers' perspectives or with the attention given to examining quality practices from managers' and employees' perspectives. Consequently, based on relevant quality management review, this article contributes to the quality management literature by fulfilling the following gap:

"To the best of our knowledge, there is no study in the field of quality management that have been comprehensively conducted to review the field itself, particularly by tracking the focus of quality management evolution over time".

This paper aims to describe how quality management field has developed and evolved to date, particularly by tracking its focus over time. In the study of quality, it is vital to understand the fundamental points where quality management comes from, before predicting where this field will be in the future. The evolution of the quality development and its interconnections over time are believed to be the factors that shape the ideas of the current progress of the quality management field. Consistent with this view, Powell (1995) makes the points that the origin of quality management can be traced by time series (i.e. Historical perspective). 
The rest of the paper is structured as follows: the first section provides the literature review on the origins and evolution of quality management. The second section discusses the methodology of the study. In the third section, the paper continues with the findings and discussion, along with research challenges in quality management and future research. The final section discusses the conclusion of the study.

\section{Origins and Evolution of Quality Management}

Authors such as (Garvin, 1988) link the era of quality management with time series; i.e., from Inspection Era to Statistical Quality Control Era, Quality Assurance Era and the latest Strategic Quality Management Era. Powell (1995) also discusses TQM relative to time. In this paper, we propose that the development and origins of quality management can also be traced to the focus of quality over the time.

Traditionally quality is used for inspection as a method of measurement to detect the errors in production manufacturing. According to Foster (2001) and Garvin (1988) the driving force of inspection activities was inspired by Frederick Taylor (the father of Scientific Management) in the early 1900s. Through the years, the interest in quality has evolved when G.S Radford published his book named The Control of Quality in Manufacturing in 1922 (Garvin, 1988 , p. 5). It defined quality as a distinct management responsibility and as an independent function yet, at that time, the primary focus was inspection (Dahlgaard, et al., 2002; Garvin, 1988, p.5). Meanwhile Henry Ford developed the Model $\mathrm{T}$ which later became the Ford car and introduced the moving assembly line, which lead to the concept of mass production (Roth, 1996; Womack et al., 1990). The Model T was described as the first product of mass production, which was developed to produce the Model T in great quantities (Batchelor, 1994, p. 66; Roth, 1996). Moreover, Womack, et al., (1990, p. 27) note that "the key to mass production wasn't - as many people then and now believe - the moving, continuous, assembly line. Rather, it was the complete and consistent interchangeability of parts and the simplicity of attaching them to each other. These were the manufacturing innovations that made the assembly line possible". This interchangeability reflects the quality in the form of standardisation, which reduce the variation in the parts.

Between 1930s and 1940s, statistics became the main method of influence for the quality management discipline. In 1938, Deming published a technical book and taught courses in the use of his statistical methods (ASQ, 2002, p. 20). Deming thinking was centred to problem solving in process management, when he proposed the Deming Cycle (Plan-Do-Check-Act). This was influenced by She- whart who at that time was concerned with the use of Statistical Quality Control (SQC) in reducing the deviation in production (ASQ, 2002).

As such Garvin (1988, p. 6) notes that in 1931, Shewhart had published Economic Control of Quality of Manufactured Product, in which he gave a precise and measurable definition of manufacturing control, developed powerful techniques for monitoring and evaluating day-to-day production, and suggested a variety of ways of improving quality. Garvin states that Shewhart's book is considered by many to be the origin of the basic principles of quality. Moreover, the book was considered by statisticians to be a landmark contribution to the effort to improve the quality of manufactured goods and he made the utmost valuable contribution to quality development with the concepts of Statistical Control or processes known today as SPC (ASQ, 2002, p. 29). Garvin adds that the development of quality management during that time was heavily influenced by statistical methods and their application. This was further developed during 1940s in the work of Bell Laboratories, which initiated and developed sampling techniques, namely Acceptable Quality Levels (AQL) and Average Outgoing Quality Limit (AOQL) (Garvin, 1988). Therefore, it is a general belief that during the period from the early 1900 s to 1940 s, the philosophy of quality was focused on the product (i.e. product focus). The process of inspection and control was aimed at detection and rejection at the point of production (i.e. How can we ensure quality in a product?).

The 1950s could be considered as the turning point of the quality management field. During that decade, the Japanese Industrial Revolution had rapidly begun. Earlier in 1946 the Union of Japanese Scientist and Engineers was founded, which went on to introduce the Deming Prize in 1951. At this time, the Japanese Industrial Standards Committee was established, and they have played a major role in the development of the quality movement in Japan. As such, several tools and techniques were implemented and are still being practiced across the world. These include Statistical Process Control (originated from Statistical Quality Control), Reliability Engineering, Kaizen and Genba-Kaizen, Failure Mode and Effect Analysis, Poka-Yoke (mistake proofing), Jidoka and Just-in-Time and Total Preventive Maintenance (Foster, 2001; Richardson, 1997).

Meanwhile, Juran published his first edition of the Quality Control Handbook in 1951. Its initial chapter discusses the economics of quality and proposes the famous analogy gold in the mine. He divided quality into avoidable and unavoidable causes (Costs of Quality). As such, in Statistical Quality Control, he estimates that $15 \%$ of quality problems in a company are due to special causes, which means that they may involve the workers. In his view, $85 \%$ or more are down to management dealing with the system (quality in the operation system). Therefore, he believes that problems can be solved by moulding the processes of 
the system.

In 1961, Feigenbaum published his book on Total Quality Control (TQC). He argued for a systematic or a total approach to quality, requiring the involvement of all functions, not just manufacturing, in the quality process. He argued that the underlying principles of this total quality are to provide genuine effectiveness control which must start with the design of the product and end only when the product has been placed in the hands of the satisfied customer. In short, quality starts to become a must in every process. It is clear that the idea was to build in quality at an early stage rather than inspecting and controlling quality at the end of the production process.

In Japan, Ishikawa developed the Ishikawa Diagram as a management problem solving tool in 1943 (Dahlgaard, et al., 2002, p. 90; Ishikawa, 1985, p. 64). In the early 1960s, Ishikawa produced a non-technical quality analysis textbook for quality circle members. Ishikawa's quality circles where first piloted at the Nippon Telegraph and Cable Company in 1962. He published a book entitled "What Is Total Quality Control" in which seven basic tools (7 Quality Tools) were described as indispensable for quality control (Ishikawa, 1985, p. 198).

In turn, another Japanese guru in quality management progress is Taguchi. In 1951, he won the Deming Award for Literature on Quality and in 1960 he won the Deming Application Prize. Along the way, Taguchi developed the concept of the "quality loss function" and his methods are concerned with the routine optimisation of product and process prior to manufacture, rather than reliance on the achievement of quality through inspection. Concepts of quality and reliability are pushed back to the design stage. The Design of Experiments (DOE) method provides an efficient technique to design product tests prior to entering the manufacturing phase (Foster, 2001; Richardson, 1997, p. 9). This method is aligned with the concept proposed by Feigenbaum where quality is built in to every process of production. It seems that at this stage the focus of QM has moved from product to process (i.e. How can we ensure quality in process?).

In 1979, standards, quality accreditation and quality systems were first introduced, with British Standard (BS) 5750 since revised in 1987 (Bank, 2000; Callan, 1992; Hill, MacGregor, \& Dewar, 1996), and which later became the BS EN ISO 9001:2000. Meanwhile, Womack et al., (1990, p. 159) claim that Ford started a systematic supplier grading system, called Q1, in the mid-1980s. This is a complex statistical system, which ranks suppliers by the number of defects discovered in the assembly plant, delivery performances, progress in implementing quality, improvement programs in the supplier plant, level of technology and management attitudes. The aim was to bring every supplier gradually up to higher and higher levels of performance and quality.

Following on from this, 1987 was a pivotal year for quality management when the International Standards for Organisation (ISO) and The Malcolm Baldrige National Quality Award were established. ISO developed the ISO 9000 series that set out methods by which a system can be implemented, to ensure that the specific quality requirements are fulfilled (ASQ, 2002). On the other hand, the criteria for Malcolm Baldrige Model were established by the approach that reflected a consensus of best practice, and an annual review process was put in place to ensure that the Baldrige Model continues to reflect evolving trends (Hakes, 1999).

The development of a standard European approach followed quickly on from the Baldrige experience. In September 1988, the leaders of 14 major European countries played a key role in establishing the European Foundation for Quality Management (EFQM). EFQM established its own model in 1991, named Business Excellence Model for the European Quality Award, which built upon the Deming and Malcolm Baldrige approaches (Hakes, 1999). Looking at the system as a whole, it covers all processes that are embedded within it. All of these models recognise the interdependencies between various components in the system (i.e. leadership shapes strategy, people, standardise processes, and cause and effect relationships) as all of these are interrelated. For example, Malcolm Baldridge Model consists of processes for meeting the company quality goals as these processes are measured by information management, strategic quality planning, human resource management, product and process management, and part of the customer focus and satisfaction category. While EFQM system recognises how leadership drives policy and strategy that is delivered through people, partnerships and resources, and processes. Therefore, it is suggested that all of these integrated managerial systems reflect the system focus. As it is clearly seen, the quality journey during this period from the 1960 s to 1980 s focused on the system (i.e. How can we ensure quality in the system?).

Crosby's first book "Quality Is Free" in 1979 sold over 2 million copies and has been translated into 15 languages. Much of "Quality Is Free" is devoted to the concept of zero defects, which is a way of explaining to employees the idea that everything should be done "right first time", that there should be no failures or defects in work outputs. His thinking places greater attention on the people aspects of quality management (Crosby, 1979). Meanwhile, in 1984, Crosby published his second bestseller "Quality without Tears". The 14 points that Crosby considered essential involve the following ideas: management commitment, education and training, measurements, cost of quality, quality awareness, corrective action, zero defects, goal setting and recognition (Crosby, 1984). Therefore, it is fair to say that Crosby initiates a new perspective on quality which considers it through organisational lenses.

During the 1990s, Total Quality Management (TQM) became central in the agenda of top management. According to Dahlgaard and Dahlgaard (2003) Total Quality Management (TQM) is a relatively new management 
philosophy, which has evolved from the rather narrow and mechanistic approach of Statistical Quality Control (SQC) as discussed earlier, to a more holistic and humanistic approach. The concept of TQM is a logical development of the concept of Total Quality Control (TQC), as introduced by Feigenbaum in 1961. In addition, another humanistic-oriented quality standard named the Investors in People (IIP) was launched in October 1991, based on widely-accepted principles of best training and development practices to enable organisations to improve their training and enhance their performance (Mason, 1997, p. 1).

Slowly but gradually, by this time, there seems to be more attention given to people with the system (people spin), in the development of quality journey. As these can be seen with the increased focus on Investors in People (1991) for the Best Training and Development Practices, European Foundation for Quality Management (1992) for the Business Excellence Model (BEM); e.g. leadership with excellent mindset and OHSAS 18000 (1996) for Occupational Health and Safety Management System.

Following on from this, the emphasis on system focus still continues with Six Sigma and Lean Manufacturing made the headlines during the 1990s. Mikel Harry (Motorola) first published "The Nature of Six Sigma" in 1986 and commercialised Six Sigma as a vibrant quality-improvement methodology (Eckes, 2005). The technique was given global boost in 1998 by Jack Welch then CEO of General Electric (Eckes, 2005; Miles, 1999). Another philosophy emerging at this time was Lean Manufacturing which derives from the Toyota Production System (TPS) or Just in Time (JIT) manufacturing. The lean manufacturing concept was popularised in American factories in large part by the Massachusetts Institute of Technology, who studied the movement from mass production toward Lean production as described in "The Machine That Changed the World: The Story of Lean Production" (Womack et al., 1990).

Systems have further developed with the implementation of TickIT, originally set up by UK Department of Trade and Industry and administered by British Standards Institution (BSI). This standard applies to suppliers of all types of information systems that involve software development processes. Further, the International Automotive Task Force (IATF) has developed ISO/TS 16949 for automotive related products. The system enables continuous improvement, emphasizing defect prevention and reduction of variation and waste in the supply chain. ISO/TS 16949 mainly applies to design/development, production, installation and servicing of automotive related products, and is the replacement of QS 9000: 1998 - International Automotive Task Force (IATF, 2002). Therefore, this was the time when overlapping occurred within the quality movement journey with the focus on both systems and people.

Moving to the late of 2000, there seems to be an increased awareness of Corporate Social and Environmental
Responsibility that obliges the business sector to play a sensible yet not solely profit-oriented role. This includes social and environmentally driven actions, where the business sector has been expected to go beyond its moneymaking and commercial activities to commit to the well-being of the community. This has led to the introduction of ISO 26000 (standards for Social Responsibility), which published in 2010 that act as a guideline for dealing with corporate social responsibility and the environment.

Castka and Balzarova (2008) insist that the new ISO 26000 should be closely aligned with ISO 14000 and requires organisations to develop their management systems around their social responsibility (i.e. people orientation) aspects and impacts. Thus, several years after the introduction of ISO 9000, global discussions was taking place related to GATT (the General Agreement on Tariffs and Trade, which was a predecessor to the World Trade Organization), aiming to remove as many obstacles as possible to international trade (P. Castka, Prajogo, Sohal, \& Yeung, 2015). The ISO 9000 has been revised to the new revision, ISO 9000:2015 is based on a number of quality management principles, including a strong customer focus, the motivation and implication of top management, the process approach and continual improvement. Da Fonseca (2015) mentions that ISO 14001 is an International Standard of worldwide acceptance based on the concept that better environmental performance can be achieved when environmental aspects are systematically identified and managed giving a major contribution to sustainability, through pollution prevention, improved environmental performance and complying with applicable laws.

In turn, the emphasis on risk management is the biggest of several changes in the third version of ISO 13485 (McMenamin, 2016). New changes in ISO 13485:2016 is the requirements for a quality management system specific to the medical device industry. Another ISO quality standard evolves to the latest is the ISO 37001 standard, published on October 15, 2016, called "Anti-bribery management systems - Requirements with guidance for use" is a useful tool to tackle corruption (Valerio, 2017). Over time, it is becoming clear that the quality focus has moved from a system focus to a people focus. It is clear that the development of quality management is focused on people with an extended view towards corporate social responsibility, environment and risk management. In fact, it is also fair to say that the risk focus turn to be the main leading idea with the establishment of ISO 31000 standard and the new revision of ISO 9001 standard. In other words, from the beginning of the 1980s to the millennium the main idea is centred on understanding how can we ensure quality in people?.

Continuing from there, a new type of work emerges that is different from both the manual-work and knowledge-work. The organising principle is fast moving towards netocracy, with flexible, flat and ever emerging trans-organisational networks where small organisations, 
and even individuals, are forming and reforming global collaborative networks to deliver innovative value propositions to global markets and customers (Hamel, 2007; Malone, 2004). Netocracy in the context of social governing reflects the idea of moving from an industrial society where social values are money driven to a humanitarian society which is knowledge driven (Bititci et al., 2008; Grant, 2008).

As such, this includes cloud manufacturing (CMfg) where it is a computing and service oriented manufacturing model developed from existing advanced manufacturing models (e.g. ASP, AM, NM, MGrid) and enterprise information technologies under the support of cloud computing, IoT, virtualization and service-oriented technologies, and advanced computing technologies (Tao, LaiLi, $\mathrm{Xu}, \&$ Zhang, 2013). It aims to realize the full sharing and circulation, high utilization, and on-demand use of various manufacturing resources and capabilities by providing safe and reliable, high quality, cheap and on-demand used manufacturing services for the whole life cycle of manufacturing (Tao et al., 2013).

Further, in a CMfg system, various manufacturing resources and abilities can be intelligently sensed and connected into the wider internet, and automatically managed and controlled using IoT technologies e.g. radio frequency identification (RFID), wired and wireless sensor network, embedded system (Tao, Cheng, Da Xu, Zhang, \& Li, 2014). Inevitably, the manufacturing resources and abilities are virtualized and encapsulated into different manufacturing cloud services (MCSs) that can be accessed, invoked, deployed, and on-demand used based on knowledge by using virtualization technologies, service-oriented technologies, and cloud computing technologies (Tao et al., 2014).

This period can be seen as the focus shifting to networks focus. It is heavily about managing/leadings networks, people with multiple networks and networks of networks. An example of this, the MCSs are classified and aggregated according to specific rules and algorithms, and different kinds of manufacturing clouds are constructed. Different users can search and invoke the qualified MCSs from a related manufacturing cloud, according to their needs, and assemble them to be a virtual manufacturing environment or solution to complete their manufacturing task involved in the whole life cycle of manufacturing processes under the support of cloud computing, service-oriented technologies, and advanced computing technologies (Tao, Zhang, Venkatesh, Luo, \& Cheng, 2011). This leads to the central question of how can we ensure quality in people in the network environment?

Today's it has seen rapid advances in connectivity, mobility, analytics, scalability, and data, spawning what has been called the fourth industrial revolution, or Industry 4.0 (Foidl \& Felderer, 2015). Aligning with the era of digitization, quality field has taken initiative to bring Quality 4.0 by a long list of technology advances in several arenas that together enable innovation, new insights, connectivity between people, and connectivity between people and machines (Jacob, 2017).

The powerful new data available to companies, together with new configurations and capabilities of smart, connected products, is restructuring the traditional functions of business - sometimes radically. This transformation started with product development but is playing out across the value chain. As it spreads, functional boundaries are shifting, and new functions are being created. Smart, connected products requires a fundamental rethinking of design. At the most basic level, product development shifts from largely mechanical engineering to true interdisciplinary systems engineering (Porter \& Heppelmann, 2015). Products have become complex systems that contain software and may have as much or more software in the cloud.

Industry 4.0 makes factories more intelligent, flexible, and dynamic by equipment manufacturing with sensors, actors, and autonomous systems (Roblek, Meško, \& Krapež, 2016). Accordingly, machines and equipment achieve high levels of self-optimization and automation. In addition, the manufacturing process has the capacity of fulfilling more complex and qualified standards and requirements of products, as expected (Roblek et al., 2016). Thus, intelligent factories and smart manufacturing are the major goals of Industry 4.0 (Sanders, Elangeswaran, \& Wulfsberg, 2016).

Consistent with this, Albers, Gladysz, Pinner, Butenko, and Stürmlinger (2016) analyse quality-related production with an intelligent condition monitoring-based quality control system and develop a comprehensive descriptive model. Similarly, in order to achieve transparency and productivity of big data, (Lee, Kao, \& Yang, 2014; Vijaykumar, Saravanakumar, \& Balamurugan, 2015) address the trends of manufacturing service transformation and the readiness of smart predictive informatics tools. The prognostics-monitoring system is a trend of the smart manufacturing and industrial big data environment (Lee, Kao \& Yang, 2014; Vijaykumar, Saravana Kumar \& Balamurugan, 2015). This point out that at the most current rate, the quality focus has extended the view from a networks focus to a smart focus with the pivotal question now is about how can we ensure quality in people in the smart environment?

\section{Research methodology}

In this paper, literature is important that it is considered as the key part of the research methodology. Therefore, in designing the research, we have opted to use a structured approach for selecting literature for review. In general terms, a literature review can be defined as the process of describing and criticising relevant literature, which others have published in that particular subject area. In order to make sense of the literature, and to find out the literature pertinent to quality management, the literature search begins by identifying who the gurus and experts are in this 
field, and then reviewing at their published works. Therefore, this study followed Martinez et al. (1998), who claim that the quality management movement can be tracked by looking at the Crosby, Deming, Feigenbaum, Ishikawa and Juran works', as they can be considered the most important gurus of the quality management field.

Thus, in the field of quality management, the gurus have been identified and universally agreed upon (Foster, 2001, pp. 35-49; Richardson, 1997, pp. 92-93); they are Walter Shewhart, Edward Deming, Armand Feigenbaum, Philip Crosby, Joseph Juran, Kaoru Ishikawa, Masaki Imai, Taiichi Ohno, and Genichi Taguchi. Identifying the gurus and the scholars in this field makes it possible for us to review their works, which are, mainly, in the form of books and journal articles. This allows us to build on their ideas and further investigate the particular issues by looking in-depth at the literature via an online database journal, such as Emerald, Science Direct, and ABI/Pro-Quest. These online databases cover journals in the area of quality management, namely the Journal of Production and Operations Management, Journal of Total Quality Management and Business Excellence, International Journal of Operation and Production Management, International Journal of Quality and Reliability Management, California Management Review, Managing Service Quality, The TQM Magazine, Journal of Operations Management, as well as other leading general management journals.

Further, a systematic approach to literature review is based on the knowledge that gives a major role in evidence-based practices (Denyer \& Tranfield, 2008; Rousseau, Manning, \& Denyer, 2008; Tranfield, Denyer, \& Smart, 2003) was adapted in this research. In the essence of this, a substantial literature review that was published by Ahire et al. (1995) were referred. This was a mainly descriptive review, providing a thorough synthesis of articles published from 1970 to 1993 and categorizing the literature along the several components of QM. Likewise, Martinez et al. (1998) also have provided a substantial literature review of articles published from 1986 to 1997 and categorizing the literature according to the number of references with the terms TQM, quality management (QM) and total quality (TQ). Similar to this, (Sousa \& Voss, 2002) also put forward their view to synthesize, organize and structure knowledge from an academic/research standpoint and offer suggestions for future research of quality. Schroeder et al. (2005) further reinforced this by reviewing papers on quality from 1992 to 2003 which mainly regarding the Total Quality Management (TQM) issues. While, Dahlgaard-Park, S.M. has reflected the quality movement (i.e. The evolution patterns of quality management and the evolution of Total Quality Management) through the work of Dahlgaard-Park, S.M. (1999, 2011). All of these reviews were a useful stepping-stone in helping to consolidate the field.

Essentially, systematic reviews are formulated around research questions, and the criteria for inclusion and ex- clusion of papers are clearly defined at the outset (Denyer \& Tranfield, 2008; Rousseau et al., 2008; Watson, Wilson, Smart, \& Macdonald, 2018). In this study, process in getting literature review that has been conducted includes the inclusion of quality management in general, as well as 'evolution of quality management' and 'development of quality management'. However, considering the objectives of this work, we found that the inclusion and exclusion criteria were emerging as we developed greater insights in quality management and global trends (i.e. Industrial Revolution 4.0 and Digital Manufacturing). We believe this dynamic and iterative nature of the literature review conducted, while not strictly following a systematic literature review approach, provided a 'fit for purpose' protocol for the intended purpose (see (Bititci, Garengo, Dörfler, \& Nudurupat, 2012; Macpherson \& Jones, 2010). The illustration of the protocol is presented in Figure 1, as in the following paragraphs.

Following from there, the initial search identified over 79,000 articles (See Table 1), which was reduced in two ways, based on the insights that were emerging from the parallel literature review on emerging global and business trends, and the researchers' previous knowledge of the field. This ensured that key contributions previously unknown to us were not missed. Obviously, it was still impossible to include all the articles that made a contribution. Also, it should be noted that the focus of the review was to identify the extant literature rather than reviewing and discussing all relevant contributions, as many contributions built upon each other (See Ahire et al. (1995), Martinez et al. (1998), Sousa and Voss (2002), Schroeder et al. (2005) and Dahlgaard-Park, S.M. (1999, 2011). In conducting the review, our objective was to describe how quality management field has developed and evolved to date, particularly by tracking its focus over time. Thus, we specifically looked for the key events and research question that were being addressed rather than identifying specific solutions, models and frameworks.

In parallel, we explored general literature on global and business trends. Here our objective was to uncover the global and business trends that are predicted for the near future in order to provide a contextual basis against which 


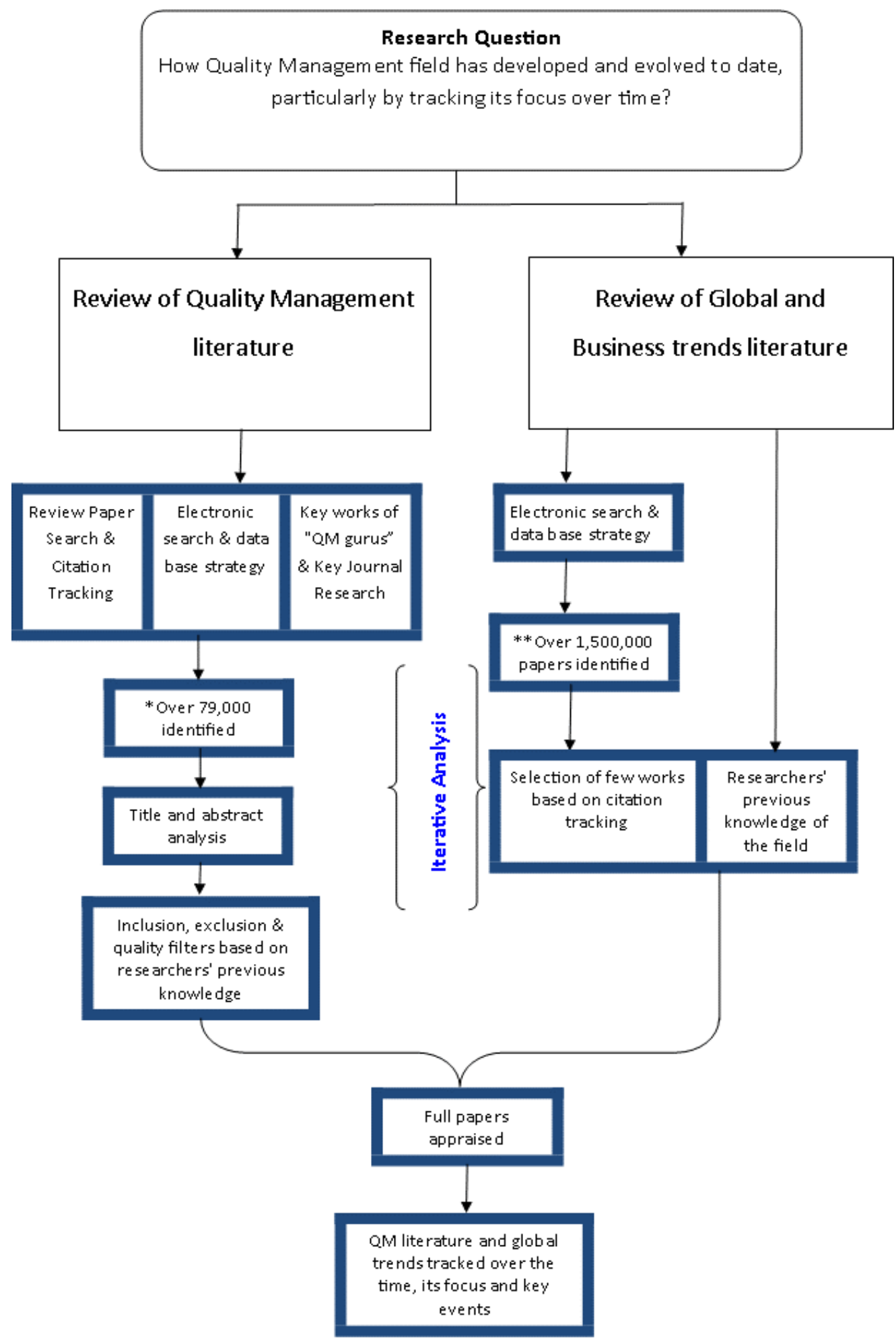

Figure 1: The methodological basis of the literature review. Source: Adapted from Bititci et. al (2012) 
Table 1: Results of the qualitatively assessed identified papers

\begin{tabular}{|l|l|l|}
\hline \multirow{2}{*}{} & \multicolumn{2}{|c|}{ Keywords Search } \\
\cline { 2 - 3 } & $\begin{array}{l}*(\mathrm{a}) \text { "Quality Management" or "Evolution of Quality } \\
\text { Management" }\end{array}$ & $\begin{array}{l}* *(\mathrm{~b}) \text { "Global” or "Global Trends" or } \\
\text { 'Business Trends' }\end{array}$ \\
\hline EBSCOhost & 24,583 & 978,307 \\
\hline ProQuest & 37,699 & $1,516,047$ \\
\hline Web of Science & 31,116 & $1,121,332$ \\
\hline Scopus & 79,884 & $1,372,791$ \\
\hline
\end{tabular}

Note: Keyword search was performed in November 2018.

we could synthesize the quality management literature. Our initial search of the popular research databases with key words such as 'global', 'global trends' and 'business trends' resulted in over 1.5 million possible articles. Consequently, rather than conducting an exhaustive review of the literature, which would have been impractical and of little additional value, we have followed the work of Bititci et. al (2012) who pinpoint the works of a few 'gurus' such as Drucker, Mintzberg, Porter and Prahalad as the basis living contemporary gurus. We started by identifying the most significant commentators, including both academic and non-academic authors of the global trends. To this end, we consulted sources such as the http://www.thinkers50. com and 'Who are the gurus' gurus?' and What's the Big Idea? (Davenport \& Prusak, 2003; Prusak \& Davenport, 2003). We gathered the most important messages from these thinkers and extrapolated these in the context of the quality management key events that emerging from the literature. This approach provided us with a picture of the global and business trends that most relevant from a quality management perspective.

\section{Findings and Discussion from literature review}

This finding of the literature review is presented with a particular emphasis on how the development of the quality field tracked or related in terms of focus, principles, systems, and tools and techniques. We have followed the Dale's framework (Dale, 1994) of principles, systems, and tools and techniques. In order to describe this quality field using this framework, definitions of the framework terms are stated for clarity.

According to Slack, et al., (2006) principles are "the core ideas that describe how operations behave, how they can be managed, and how they can be improved. They are not immutable laws or prescriptions that indicate how operations should be managed, nor are they descriptions that simply explain or categorise issues". In this research, the we defines principles as the core ideas or the fundamental ways of thinking in performing things.

Betz (1998, p. 39) defines the concept of a system as "to look at a thing, an object, with a view to seeing it as a totality, displaying change, and encompassed in an environment". Additionally, American Society for Quality - (ASQ, 2002, p. 8) define a system as "a set of interrelated or interacting processes". Consistent with this, the we have synthesised their definitions and proposes that a system is a set of interrelated or interacting processes with a view to seeing it as a totality, displaying change, and encompassed in an environment.

Borrowing the definition from American Society for Quality (2002), a tool is defined as "a device used to help accomplish the purpose of a technique". In line with this and the work of (Phaal, Farrukh, \& Probert, 2004), we defines a tool as something that facilitates the practical application of a technique and a technique is a structured way of completing part of a procedure.

According to the literature, quality management evolution can be divided into five specific eras, which are: (1) Quality Inspection (QI), (2) Quality Control (QC), (3) Quality Assurance (QA), (4) Total Quality Control (TQC), and (5) Total Quality Management (TQM). It should be noted that the terms used here are based on the emerging focus throughout the evolution of quality management. Consequently, the focus is believed to drive the principles, systems, and tools and techniques in the development of each quality era. Based on the review presented in the previous section, allowed the the researchers to identify nine quality management principles, these are namely as; 1. Continuous quality improvement, 2. Conformance to standard, 3. Management understanding, 4. Customer orientation, 5. Quality leadership, 6. Involvement, 7. Quality supplier relationship, 8. Process management and 9. System Management. Each era will now be discussed according to the framework introduced earlier.

Quality Inspection (QI) Era

During this period, quality was associated with inspection (J. J. Dahlgaard et al., 2002; Garvin, 1988, p. 5). Accord- 
ingly, "at one time inspection was thought to be the only way of ensuring quality" (Dale, 2003, p. 22). Further, Dale (2003) based on BS EN ISO 9000 - British Standards Institute (2000) defines quality inspection as the "degree to which a set of inherent characteristics fulfils requirements". It is clear this period was focused around products.

\section{Principles of Quality Inspection}

Along the path of Quality Inspection era, the primary principle of quality was stressed as sorting good from bad, with continuous quality improvement based on the corrective action basis. The idea was to commit solely to conformance to product standards. The management understanding during this time laid on specialisation of labour that means every worker has his own task. This principle can be traced back to when Henry Ford came introduced the implementation of task separation and mass production manufacturing. The leadership style at this time was about command. In fact, the management understanding towards quality was very shallow with the assumption that quality was a subordinate to cost, and customers were seen as a necessary evil, as evidenced by the infamous quotation, "Any customer can have a car painted any colour that he wants so long as it is black" (Batchelor, 1994) based on (Ford, 1922). Therefore, the consumers bought what was available as the economy was dominated by the producers.

\section{Systems}

It is fair to say that the Ford mass production system was the main comprehensive system around during the QI era. This system combined all elements of a manufacturing system, consisting of people, machines, tooling, infrastructure (factory) and products, which worked together in a continuous system for manufacturing the Model T automobile (Batchelor, 1994). Therefore, the production system could be considered as the formal system that emerged at this point of time.

\section{Tools and techniques}

Inspection technique and moving assembly line could be considered as the key tools and techniques in this period, as inspection was used to grade the finished product and a moving assembly line made it possible for producing products in great numbers.

\section{Quality Control (QC) Era}

Continuing from the quality inspection era, the next movement was about quality control (J. J. Dahlgaard et al., 2002; Dale, 2003; Garvin, 1988). As a consequence, previous work by quality gurus such as Fredrick W. Taylor, Walter Shewhart, G.S Radford, Deming and Ishikawa stressed inspection activities that are linked more formally to quality control. Indeed, product was still the key focus during this era (i.e. product focus).

\section{Principles of Quality Control}

In this Quality Control era, one of the main ideas in continuous quality improvement was the use of statistical tools to control process output. However, at this time, quality improvement was limited to corrective action (i.e. finding and fixing problems). In term of conformance to standard, the idea was solely about meeting quality standards (i.e. product standard). Clearly, the ideas during this time were still on specialisation of labour and the assumption that quality was secondary to cost. Yet slowly and gradually, systematic documentation and the review of product specifications, inspection procedures and responsibilities emerged and became the central ideas during the QC era.

In the principle of leadership, command and control were the centred idea during this era. The products produced were depended on what the producers supplied. As it was not based on market demands customers had no freedom to select. The product quality was based on the perspective of the producer without the customers involvement. Process management was still fragmented at this time. Dale (2003, p. 23) claims that, "there was lack of creative and systematic work activity, with planning and improvements being neglected and defects being identified late in the process". For instance, the principle of system management occurred and it was about the product. The emphasis of the system was about the understanding of the isolated cause and effects in product quality.

\section{Systems}

In this period, no new system emerged with the production system still dominating during this era.

\section{Tools and techniques}

Several tools and techniques such as Statistical Quality Control (SQC), inspection link to quality control, sampling Acceptable Quality Levels (AQL), Average Outgoing Quality Limit (AOQL) and Total Preventive Maintenance (TPM) emerged and made an impact during the QC era. It is clear that statistical analysis became so influential played a big part in the movement of quality control during this period.

\section{Quality Assurance (QA) Era}

According to Dale (2003, pp. 24-25) quality assurance is about a "prevention-based system which improves product and service quality, and increases productivity by placing the emphasis on product, service and process design". While (Ishikawa, 1985, p. 75) defines quality assurance as a means to "assure quality in product so that a customer can buy it with confidence and use it for a long period with confidence and satisfaction". Accordingly, in this era, the focus of quality management shifted from product to process.

\section{Principles of Quality Assurance}

The principle of continuous quality improvement during this time seemed to be rather systematic but fragmented 
improvement, with the agenda of quality improvement shifting from corrective action to preventive action. Thus, the quality conformance had changed from product to process standards in the operational system. On top of that, from a management understanding view, emphasis was on multi-skilled labour and not only about specialisation of labour as in previous times. Hence, the management understanding brought the idea of systematic documentation and review of quality policies, procedures and responsibilities (e.g. Quality Management System). This was a proactive approach rather than the reactive approach in the QC era. By this time, the principle of customer orientation had evolved to understanding customers' requirements through capturing, documenting and reviewing them as part of the quality process. The changes in quality principles of leadership became more systematic, where leadership was driven by the quality system orientation (leadership in the system) with some elements of control (i.e. decision-making and rectifying problems). In spite of that, the quality principles of involvement and supplier relationships were slow to emerged. At this stage, controlled involvement and controlled partner relationships had occurred. For example, staff in the organisation could be involved in quality programs and activities but still under the control of management. The same case applied with supplier relationships.

In short, involvement and supplier relationships became the issues and key ideas in quality development. Looking at the principle of process management and system management the transition happened from fragmented to integrated process control in the quality process; as there was recognition of quality as a process in itself. While system management underline the understanding of simple causes and effects in the process and discrete proven process (the quality system and practices were likely to have met as a minimum requirement). This suggests that the principle of the system management was not fully applied until the adoption of a systems approach during the Quality Assurance era.

\section{Systems}

Quality Assurance era could be considered as the focal point for the formal development of quality management systems. For example, the Deming Model was the comprehensive measurement system of quality standards developed during this time in 1951. The release of British Standard (BS) 5750 and International Standard Organisation (ISO) 9000 series were the formal quality systems that made a mark during this time. In line with this, Total Preventive Maintenance (TPM), which was primary focused on techniques for maintenance of assets (i.e. product and machine maintenance), evolved to Total Productive Maintenance (TPM) that focuses on productivity of entire system (including man, machine, method etc). This means that the Preventive Maintenance, which was very much process focused, became system focused by moving to To- tal Productive Maintenance (i.e. shifting to system focus).

\section{Tools and techniques}

During this era, the revolution of tools and techniques rapidly occurred. Plan-Do-Check-Act (PDCA) was extended to become Plan-Do-Study-Act (PDSA). Further, Cause and Effect Diagram, Failure Mode and Effect Analysis (FMEA), Reliability Engineering, Statistical Process Control (SPC), Kaizen, Kanban, Jidoka and Just-In-Time (JIT) were among the tools and techniques that emerged at this era.

\section{Total Quality Control (TQC) Era}

Total Quality Control era reflected the development of quality systems orientation in the context of quality management development. In some cases, there was an overlap in the context and application of tools and techniques, as this was the time when the focus of quality management shifted from process to systems. Ideally, the boundaries of quality had extended to a bigger scope, which completely covered the entire process embedded in the system. As noted by Feigenbaum (1961), "total quality control is an effective system for integrating the quality development, quality maintenance and quality improvement efforts of the various groups in an organisation so as to enable marketing, engineering, production and service at the most economical levels which allow for full customer satisfaction".

\section{Principles of Total Quality Control}

The changes in the principles of continuous quality improvement can be seen as it became much more systematic and manageable. We would describe this as systematic managed continuous improvement. Accordingly, the line of thinking improved with managed prevention and improvement. In terms of conformance to standard, it was about conformance to a systematic improvement standard which was managed by a team (i.e. Quality Control Circle and Problem Solving Group). As such, the management understanding evolved with the understanding of the need of multi-skilled and cross-functional teams working to improve quality on a daily basis. Team working became central to ensuring quality. This understanding included managing systematic use of tools and techniques, and facilitating objective and structured management. Occasionally, this was the time where quality was perceived as a project driven journey. On top of that, the idea of customer orientation transformed to customer satisfaction by fulfilling and exceeding customers' requirements. The principle of leadership changed to be more participatory where the leaders (i.e. top management) encouraged all staff to take responsibility for quality and managed the involvement of workers (e.g. Quality Control Circle and Kaizen activities). At this time, the issues of managing involvement and partnership relationships emerged in a quality context. Further, process management evolved and became more systematic, while system management dealing with the 
understanding of complex causality in the operational processes.

\section{Systems}

The changing from quality assurance to total quality control era includes changes in quality systems deployment. The systems that emerged in this period were Toyota Production System (TPS), ISO 9000 revision 1992, Ford Q1 System, QS 9000, ISO 14000, OHSAS 18000 and TickIT. This reflected the progression of new standards in TQC era. In short, quality standards became the most dominant systems at this point.

\section{Tools and techniques}

Several tools and techniques that made the headlines during this time were Quality Loss Function, Quality Functional Deployment (QFD), Poka Yoke, Quality Control Circle (QCC), 7 Quality Tools (i.e. Pareto Analysis; Fish Bone Diagram; Stratification; Check sheet; Histogram; Scatter Diagram and Control Chart), Benchmarking, Lean tools and techniques, and Single Minute Exchange of Die (SMED).

\section{Total Quality Management (TQM) Era}

Total quality management is about the cooperation of everyone in an organisation and associated business processes to produce value-for-money products and services, which meet and exceed the needs and expectations of customers (Dale, 2003). In TQM era, the quality focus is not solely about the systems but includes people, so the focus is about people in the organisation (i.e. People focus) striving towards business excellence.

Over time, the development of TQM era is still focused on people with an extended view towards global collaborative networks. This period can be seen as the focus shifting to networks focus. It is heavily about managing/leading networks, people with multiple networks and networks of networks (Tao et al., 2011).

Today, aligning with the era of digitization, TQM is integrating with the Industrial Revolution 4.0 in which involved with the technology advances in several areas that together enable innovation, new insights, connectivity between people, and connectivity between people and machines (Jacob, 2017). It is becoming clear that the quality focus now has a further extended view from network-focus to a smart-focus.

\section{Principles of Total Quality Management}

In TQM era, the evolving principles of quality are centred on the people. For instance, the quality principle of continuous improvement has evolved to become more systematic and habitual. This means that improvement is not only about managing and rectifying mistakes or problems, but becomes habitual for prevention and improvement.

During this era, conformance to standard is about conformance to systematic improvement standard, which has become habitual for the workers. From the perspective of management understanding, the transformation of ideas happened, where multi skilled cross-functional teams and the use of tools and techniques for facilitating objective and structured management have become the norm among the employees. Along with this, the principle of customer orientation transformed from customer satisfaction orientation to customer delight (i.e. exceeding customer expectation) mainly in service dominant culture, which is about adding value to customers, business, life etc. The principle style of quality leadership centred on coherent leadership with excellence mindset. Leadership goes beyond participation to a mindset of excellence. In terms of involvement, it has extended to a bigger scope, encompassing all levels and the habitual involvement of suppliers and partner in continuous quality improvement activities. By this time, process management has evolved where processes are managed as an integrated system, and system management has evolved to become a complex system, concerning the understanding of causalities in business processes including operational, managerial, support and human factors.

\section{Systems}

During this time, the quality systems that emerged and impacted on the quality management field was the Malcolm Baldrige Model, Investors in People (IIP), EFQM Excellence Model, ISO 9001 revision 2000 and 2015, Lean concept (i.e. Lean Manufacturing), ISO 14001 revision 2015, ISO/TS 16949 standards for automotives and ISO 31000 revision 2009 and 2018.

\section{Tools and techniques}

The tools and techniques that make a mark during this time include Design of Experiments (DOE), 5S (i.e. Seiri, Seiso, Seiko, Seiketsu and Shisuke) and Six Sigma.

In summary, borrowing from the work of, (Slack et al., 2006, p. 376):

"Quality was achieved by inspection - screening out defects before customers noticed them. Then the 'quality control' (QC) concept developed a more systematic approach to not only detecting but also solving quality problems. 'Quality assurance' $(Q A)$ widened the responsibility for quality to include functions other than direct operations, such as Human Resources, Accounting and Marketing. It also made increasing use of more sophisticated statistical quality techniques. TQM included much of what went before but developed its own distinctive themes, especially in its adoption of a more 'all-embracing' approach".

Table 2 provides the brief summary of this evolution of quality management field organised into the focus, principles, systems, and tools and techniques framework. It should be noted that the table should be read not in a very detailed fashion, but what is more important is that the reader need to get the big picture of this table. The table is obviously an oversimplification of the reality. However, 
it is actually done on purpose. It is impossible to capture the richness of the real world, let alone hundred years of evolution of the quality management field, and it is impos- sible to have everyone agree about the details, as different experts will have different perspectives.

Table 2: The origins and the evolution of quality management from Quality Inspection (QI) to Total Quality Management (TQM)

\begin{tabular}{|c|c|c|c|c|c|}
\hline Dimension & $\begin{array}{c}\text { Quality In- } \\
\text { spection (QI) }\end{array}$ & $\begin{array}{l}\text { Quality Control } \\
\text { (QC) }\end{array}$ & $\begin{array}{l}\text { Quality Assur- } \\
\text { ance (QA) }\end{array}$ & $\begin{array}{c}\text { Total Quality } \\
\text { Control (TQC) }\end{array}$ & $\begin{array}{l}\text { Total Quality Man- } \\
\text { agement (Business } \\
\text { Excellent, Networks and } \\
\text { Smart Environment) }\end{array}$ \\
\hline $\begin{array}{c}\text { Approximate } \\
\text { Timings }\end{array}$ & $1900 \mathrm{~s} \sim 1920 \mathrm{~s}$ & $1920 \mathrm{~s} \sim 1950 \mathrm{~s}$ & $1950 \mathrm{~s} \sim 1980 \mathrm{~s}$ & $1960 \mathrm{~s} \sim 1990 \mathrm{~s}$ & $1980 \mathrm{~s} \sim$ present \\
\hline Key References & $\begin{array}{l}\text { Garvin (1988, } \\
\text { p. 5); Foster } \\
\text { (2001, p. 44) } \\
\text { - Fredrick W. } \\
\text { Taylor } \\
\\
\text { Batchelor } \\
\text { (1994, p. 22); } \\
\text { Womack, } \\
\text { Jones, \& Roos } \\
\text { (1990, p. 26) - } \\
\text { Henry Ford } \\
\\
\text { Garvin (1988, } \\
\text { p. 5) - G.S } \\
\text { Radford }\end{array}$ & $\begin{array}{l}\text { ASQ (2002, } \\
\text { p. 29) - Walter } \\
\text { Shewhart } \\
\text { ASQ (2002, p. } \\
\text { 20) - Deming } \\
\text { Garvin (1988, p. } \\
\text { 9) - Bell Labora- } \\
\text { tories } \\
\\
\text { Dahlgaard, et al., } \\
\text { (2002, p. 90) - } \\
\text { Ishikawa } \\
\text { Nakajima } \\
\text { (1988); Rich- } \\
\text { ardson (1997) - } \\
\text { Total Preventive } \\
\text { Maintenance }\end{array}$ & $\begin{array}{l}\text { Bound, Yorks, } \\
\text { Adam \& Ranney } \\
\text { (1994, p. 58); } \\
\text { Gower (1990, } \\
\text { p. 193) - Failure } \\
\text { Mode Effect Anal- } \\
\text { ysis (FMEA) } \\
\\
\text { Garvin (1988), } \\
\text { Martinez-Lorente, } \\
\text { Dewhurst \& Dale } \\
\text { (1998) and Bank } \\
\text { (2000) - Statistical } \\
\text { Process Control } \\
\text { (SPC) } \\
\\
\text { Nakajima (1988) } \\
\text { and Richardson } \\
\text { (1997) - Total } \\
\text { Productive } \\
\text { Maintenance } \\
\text { (TPM) }\end{array}$ & $\begin{array}{l}\text { Ishikawa (1985); } \\
\text { Bank (2000); ASQ } \\
\text { (2002, p. 4) - Ishi- } \\
\text { kawa } \\
\text { Womack, et al., } \\
\text { (1990)) - Toyota } \\
\text { Production System } \\
\text { (TPS) } \\
\\
\text { ASQ (2002) - } \\
\text { Taguchi and Quali- } \\
\text { ty Loss Function } \\
\\
\text { Garvin (1988, } \\
\text { p. 198); Bank } \\
\text { (2000); Zairi } \\
\text { (1994, p. 43) - } \\
\text { Quality Functional } \\
\text { Deployment } \\
\text { (QFD) }\end{array}$ & $\begin{array}{l}\text { Womack, et al., (1990) } \\
\text { - Toyota and Lean Man- } \\
\text { ufacturing } \\
\text { Eckes (2005, p. 12) - } \\
\text { Motorola \& GE and Six } \\
\text { Sigma } \\
\\
\text { Mason (1997, p. 1) - } \\
\text { National Training Task } \\
\text { Force and Investors In } \\
\text { People }\end{array}$ \\
\hline
\end{tabular}


Table 2: The origins and the evolution of quality management from Quality Inspection (QI) to Total Quality Management (TQM) (continued)

\begin{tabular}{|c|c|c|c|c|c|}
\hline & & & $\begin{array}{l}\text { Gower (1990) - } \\
\text { Taiichi Ohno and } \\
\text { Just-In-Time (JIT) } \\
\\
\text { Garvin (1988, } \\
\text { p. 198); Foster } \\
\text { (2001, p. 36); } \\
\text { Dahlgaard, et al., } \\
\text { (2002, p. 23) - } \\
\text { Union of Japanese } \\
\text { Scientists and } \\
\text { Engineers (JUSE) } \\
\text { and Deming Prize } \\
\\
\text { Garvin (1988, p. } \\
\text { 12); Bank (2000); } \\
\text { ASQ (2002, p. } \\
\text { 22); Juran (1951) } \\
\text { - Juran Quality } \\
\text { Control Handbook } \\
\\
\text { Bank (2000); } \\
\text { w British } \\
\text { com w.bsigroup. } \\
\text { Standards Institute } \\
\text { (BSI) } \\
\text { ASQ (2002, pp. } \\
\text { 4,30,32); (Bank, } \\
\text { 2000); www.iso. } \\
\text { org - Internation- } \\
\text { al Standard for } \\
\text { Organisation, } \\
\text { Geneva }\end{array}$ & $\begin{array}{l}\text { Shingo (1985) } \\
\text { - Single Minute } \\
\text { Exchange Die } \\
\text { (SMED) } \\
\\
\text { Crosby (1979) } \\
\text { - Crosby Zero } \\
\text { Defects and "The } \\
\text { Absolutes" } \\
\\
\text { Bank (2000) - } \\
\text { Xerox Corporation } \\
\text { and Benchmarking } \\
\\
\text { Womack, et al., } \\
\text { (1990, p. 159)- } \\
\text { Ford system Q1 } \\
\\
\text { Stamatis (1996, } \\
\text { p. } 76 \text { ) - Daim- } \\
\text { ler-Chrysler, Ford } \\
\text { \& General Motor } \\
\text { and Quality Sys- } \\
\text { tem (QS 9000) } \\
\text { (1992) - TickIT } \\
\text { International Stan- } \\
\text { dard for Organisa- } \\
\text { tion; Morris (2004) } \\
\text { - ISO 14000 } \\
\text { International Stan- } \\
\text { dard for Organisa- } \\
\text { tion - ISO 18000 } \\
\end{array}$ & $\begin{array}{l}\text { International Standard for } \\
\text { Organisation; BSI (2000) } \\
\text { - ISO 9001 Revision } \\
\text { (2000) } \\
\\
\text { IATF (2002) - ISO/TS } \\
\text { 16949 } \\
\\
\text { Castka and Balzarova } \\
\text { (2008) - ISO 26000 } \\
\\
\text { International Standard } \\
\text { for Organisation (2009) } \\
\text { - ISO 31000 (Risk Man- } \\
\text { agement) } \\
\\
\text { (Bititci et al., 2008; } \\
\text { Grant, 2008; Hamel, } \\
\text { 2007; Tao et al., 2013; } \\
\text { Tao et al., 2011) - Global } \\
\text { Collaborative Networks } \\
\text { (Network Environment) } \\
\\
\text { (Foidl \& Felderer, 2015; } \\
\text { Roblek et al., 2016) - } \\
\text { Industrial Revolution (IR } \\
\text { 4.0) for Quality Manage- } \\
\text { ment } \\
\text { (Albers et al., 2016; } \\
\text { Jacob, 2017; Lee et } \\
\text { al., 2014; Vijaykumar } \\
\text { et al., 2015) - Smart } \\
\text { Environment for Quality } \\
\text { Management }\end{array}$ \\
\hline Focus & Product & Product & Process & System & $\begin{array}{l}\text { People in Organisation } \\
\text { People in Network (Net- } \\
\text { work - focus) } \\
\text { People in Smart Environ- } \\
\text { ment (Smart-focus) }\end{array}$ \\
\hline
\end{tabular}


Table 2: The origins and the evolution of quality management from Quality Inspection (QI) to Total Quality Management (TQM) (continued)

\begin{tabular}{|c|c|c|c|c|c|}
\hline Principles: & $\begin{array}{l}\text { Sorting good } \\
\text { from bad }\end{array}$ & $\begin{array}{l}\text { Use of statistical } \\
\text { tools to control } \\
\text { process output }\end{array}$ & $\begin{array}{l}\text { Systematic but } \\
\text { fragmented } \\
\text { improvement }\end{array}$ & $\begin{array}{l}\text { Systematic managed } \\
\text { continuous improve- } \\
\text { ment }\end{array}$ & $\begin{array}{l}\text { Systematic and habitual } \\
\text { continuous improvement }\end{array}$ \\
\hline $\begin{array}{l}\text { Principle } 1 \\
\text { Continuous } \\
\text { Improvement }\end{array}$ & $\begin{array}{l}\text { Corrective } \\
\text { Action }\end{array}$ & Corrective Action & $\begin{array}{l}\text { Preventive } \\
\text { Action }\end{array}$ & $\begin{array}{l}\text { Managed prevention } \\
\text { and improvement }\end{array}$ & $\begin{array}{l}\text { Habitual prevention and } \\
\text { improvement }\end{array}$ \\
\hline $\begin{array}{l}\text { Principle } 2 \\
\text { Conformance } \\
\text { to Standard }\end{array}$ & $\begin{array}{l}\text { Conformance } \\
\text { to product } \\
\text { standard }\end{array}$ & $\begin{array}{l}\text { Conformance to } \\
\text { product standard }\end{array}$ & $\begin{array}{l}\text { Conformance } \\
\text { to process } \\
\text { standard in the } \\
\text { operational } \\
\text { system }\end{array}$ & $\begin{array}{l}\text { Conformance to } \\
\text { systematic im- } \\
\text { provement standard } \\
\text { (Managed) }\end{array}$ & $\begin{array}{l}\text { Conformance to systemat- } \\
\text { ic improvement standard } \\
\text { (Habitual) }\end{array}$ \\
\hline \multirow{3}{*}{$\begin{array}{l}\text { Principle } 3 \\
\text { Management } \\
\text { Understand- } \\
\text { ing }\end{array}$} & $\begin{array}{l}\text { Specialisation } \\
\text { of labour }\end{array}$ & $\begin{array}{l}\text { Specialisation of } \\
\text { labour }\end{array}$ & $\begin{array}{l}\text { Multi-skilled } \\
\text { labour }\end{array}$ & $\begin{array}{l}\text { Multi-skilled and } \\
\text { cross-functional } \\
\text { teams (Managed) }\end{array}$ & $\begin{array}{l}\text { Multi-skilled cross- func- } \\
\text { tional teams (Habitual) }\end{array}$ \\
\hline & $\begin{array}{l}\text { Quality subor- } \\
\text { dinate to cost }\end{array}$ & $\begin{array}{l}\text { Quality subordi- } \\
\text { nate to cost }\end{array}$ & - & - & - \\
\hline & - & $\begin{array}{l}\text { Systematic doc- } \\
\text { umentation and } \\
\text { review of product } \\
\text { specifications } \\
\text { and inspection } \\
\text { procedures and } \\
\text { responsibilities }\end{array}$ & $\begin{array}{l}\text { Systematic } \\
\text { documentation } \\
\text { and review of } \\
\text { quality policies, } \\
\text { procedures and } \\
\text { responsibilities } \\
\text { (e.g., Quality } \\
\text { Management } \\
\text { System) }\end{array}$ & $\begin{array}{l}\text { Managed systematic } \\
\text { use of tools and } \\
\text { techniques facilitat- } \\
\text { ing objective/struc- } \\
\text { tured management }\end{array}$ & $\begin{array}{l}\text { Habitual use of tools and } \\
\text { techniques facilitating } \\
\text { objective/structured man- } \\
\text { agement }\end{array}$ \\
\hline $\begin{array}{l}\text { Principle } 4 \\
\text { Customer } \\
\text { Orientation }\end{array}$ & $\begin{array}{l}\text { Customer is a } \\
\text { necessary evil }\end{array}$ & $\begin{array}{l}\text { Customer has no } \\
\text { choice }\end{array}$ & $\begin{array}{l}\text { Understanding } \\
\text { customers } \\
\text { requirements } \\
\text { through } \\
\text { capturing, } \\
\text { documentation } \\
\text { and review } \\
\text { of customer } \\
\text { requirements }\end{array}$ & $\begin{array}{l}\text { Customer satisfac- } \\
\text { tion by fulfilling and } \\
\text { exceeding customers } \\
\text { requirements }\end{array}$ & $\begin{array}{l}\text { Customer delight in service } \\
\text { dominant culture adding } \\
\text { value to customers, busi- } \\
\text { ness, life etc. }\end{array}$ \\
\hline $\begin{array}{l}\text { Principle } 5 \\
\text { Leadership }\end{array}$ & Command & $\begin{array}{l}\text { Command and } \\
\text { control }\end{array}$ & $\begin{array}{l}\text { Systems and } \\
\text { control }\end{array}$ & Participatory & $\begin{array}{l}\text { Coherent leadership with } \\
\text { excellence mindset }\end{array}$ \\
\hline $\begin{array}{l}\text { Principle } 6 \\
\text { Involvement }\end{array}$ & $\begin{array}{l}\text { No involve- } \\
\text { ment }\end{array}$ & No involvement & $\begin{array}{l}\text { Controlled } \\
\text { involvement }\end{array}$ & $\begin{array}{l}\text { Managed involve- } \\
\text { ment }\end{array}$ & $\begin{array}{l}\text { Habitual involvement at all } \\
\text { level }\end{array}$ \\
\hline $\begin{array}{l}\text { Principle } 7 \\
\text { Supplier Rela- } \\
\text { tionships }\end{array}$ & $\begin{array}{l}\text { Adversarial } \\
\text { arm's length } \\
\text { (i.e. no rela- } \\
\text { tionship) }\end{array}$ & $\begin{array}{l}\text { Adversarial arm's } \\
\text { length (i.e. no } \\
\text { relationship) }\end{array}$ & $\begin{array}{l}\text { Controlled } \\
\text { partner rela- } \\
\text { tionships }\end{array}$ & $\begin{array}{l}\text { Managed partner } \\
\text { relationships }\end{array}$ & $\begin{array}{l}\text { Habitual involvement of } \\
\text { partner in continuous im- } \\
\text { provement activities }\end{array}$ \\
\hline $\begin{array}{l}\text { Principle } 8 \\
\text { Process Man- } \\
\text { agement }\end{array}$ & $\begin{array}{l}\text { No recognition } \\
\text { of the process }\end{array}$ & Fragmented & $\begin{array}{l}\text { Integrated pro- } \\
\text { cess control }\end{array}$ & $\begin{array}{l}\text { Systematic process } \\
\text { management }\end{array}$ & $\begin{array}{l}\text { Processes are managed as } \\
\text { an integrated system }\end{array}$ \\
\hline
\end{tabular}


Table 2: The origins and the evolution of quality management from Quality Inspection (QI) to Total Quality Management (TQM) (continued)

\begin{tabular}{|c|c|c|c|c|c|}
\hline $\begin{array}{l}\text { Principle } 9 \\
\text { System Man- } \\
\text { agement }\end{array}$ & $\begin{array}{l}\text { No system } \\
\text { thinking or } \\
\text { understanding }\end{array}$ & $\begin{array}{l}\text { Understanding } \\
\text { isolated cause and } \\
\text { effects in product } \\
\text { quality } \\
\text { Product }\end{array}$ & $\begin{array}{l}\text { Understanding } \\
\text { simple causes } \\
\text { and effects in } \\
\text { the process } \\
\text { Discrete proven } \\
\text { process }\end{array}$ & $\begin{array}{l}\text { Understanding } \\
\text { complex causality } \\
\text { in the operational } \\
\text { processes } \\
\text { Operational pro- } \\
\text { cesses }\end{array}$ & $\begin{array}{l}\text { Understanding complex } \\
\text { system causalities of busi- } \\
\text { ness processes including } \\
\text { operational, managerial, } \\
\text { support and human factors } \\
\text { Complex system causalities }\end{array}$ \\
\hline Systems & $\begin{array}{l}\text { Mass Produc- } \\
\text { tion System }\end{array}$ & $\begin{array}{l}\text { Mass Production } \\
\text { System }\end{array}$ & $\begin{array}{l}\text { Deming Model } \\
\text { BS } 5750 \text { Quali- } \\
\text { ty Management } \\
\text { series } \\
\text { ISO } 9000 \text { Stan- } \\
\text { dards } \\
\text { Total Produc- } \\
\text { tive Mainte- } \\
\text { nance (TPM) }\end{array}$ & $\begin{array}{l}\text { Toyota Production } \\
\text { System (TPS) } \\
\text { ISO 9000:1992 } \\
\text { Ford Q1 System } \\
\text { QS 9000 } \\
\text { ISO 14000 } \\
\text { ISO 18000 } \\
\text { TickIT }\end{array}$ & $\begin{array}{l}\text { Malcolm Baldrige Model } \\
\text { Investors In People } \\
\text { EFQM Excellence Model } \\
\text { ISO 9001:2000; } 2015 \\
\text { Lean concept } \\
\text { ISO/TS 16949 } \\
\text { ISO 14001:2015 } \\
\text { ISO 31000: } 2009 ; 2018\end{array}$ \\
\hline $\begin{array}{l}\text { Tools \& Tech- } \\
\text { niques }\end{array}$ & $\begin{array}{l}\text { Inspection } \\
\text { Moving assem- } \\
\text { bly line }\end{array}$ & $\begin{array}{l}\text { Statistical Quality } \\
\text { Control (SQC) } \\
\text { Inspection link to } \\
\text { quality control } \\
\text { Sampling Ac- } \\
\text { ceptable Quality } \\
\text { Levels (AQL) } \\
\text { Average Outgoing } \\
\text { Quality Limit } \\
\text { (AOQL) } \\
\text { Total Preventive } \\
\text { Maintenance }\end{array}$ & $\begin{array}{l}\text { Plan-Do- } \\
\text { Check-Act } \\
\text { (PDCA) } \\
\text { Extend PDCA } \\
\text { to become } \\
\text { Plan-Do-Study- } \\
\text { Act (PDSA) } \\
\text { Cause and Ef- } \\
\text { fect Diagram } \\
\text { Failure Mode } \\
\text { Effect Analysis } \\
\text { (FMEA) } \\
\text { Reliability } \\
\text { Engineering } \\
\text { Statistical } \\
\text { Process Control } \\
\text { (SPC) } \\
\text { Kaizen } \\
\text { Kanban } \\
\text { Jidoka } \\
\text { Just-In-Time } \\
\text { (JIT) }\end{array}$ & $\begin{array}{l}\text { Quality Loss Func- } \\
\text { tion } \\
\text { Quality Functional } \\
\text { Deployment (QFD) } \\
\text { Poka Yoke } \\
\text { Quality Control } \\
\text { Circle (QCC) } \\
7 \text { Quality Tools } \\
\text { (Pareto Analysis, } \\
\text { Fish Bone Diagram, } \\
\text { Stratification, Check } \\
\text { Sheet, Histogram, } \\
\text { Scatter Diagram, } \\
\text { Control Chart) } \\
\text { Benchmarking } \\
\text { Lean tools and } \\
\text { techniques } \\
\text { Single Minute } \\
\text { Exchange of Die } \\
\text { (SMED) }\end{array}$ & $\begin{array}{l}\text { Design of Experiments } \\
\text { (DOE) } \\
5 \mathrm{~S} \\
\text { Six Sigma }\end{array}$ \\
\hline
\end{tabular}




\section{Research challenges in quality management}

\section{Implications of the research}

As a result of this research, the managerial implications for future work are as follows:

Investigating a single organisation is futile, since the organisation will form part of a network. For example, there is less value for future research in continuous improvement based solely in a single company because in the future, it is about the improvement that comes from the network. The interactions and relationships throughout the network should be considered (i.e. internal and external ideas/innovation).

Further, future research should not only focus on a specific issue (e.g. continuous improvement for product design) and neglect to other issues/factors around it. It should consider the entire system. This means that the future researcher needs to understand the whole picture of the process internally and externally, as the future is not only about managing a specific problem in a single company, but what matters is how companies managing and dealing the wide resources of improvements and innovation across the networks with the architectural of participation and collaboration that come from all over the world (i.e. high involvement of communities of practice).

The fact that the future will be more about network, key quality principles such as; continuous improvement, standards, leadership and partnerships in the future will be managed in a network context (i.e. open source, open innovation, "smart" environment). For example, Sony has moved from lean production to open source, where Sony Corporation and Google Inc. announced an alliance to provide a range of new and rich entertainment experiences that combine Google's open-source Android OS platform with Sony's expertise in technology and product design. The two companies are exploring the joint development of compelling new Android-based hardware products for the home, mobile and personal product categories and are also exploring extending the alliance in connection with Sony's wide range of entertainment assets to establish new forms of cloud-based user experiences (Perakakis, 2017). Through this alliance, Sony aims to leverage the stability, future growth potential and open-source accessibility of Google's Android platform to further optimise its product development processes while also providing consumers with an open, expansive and evolving user experience (See also Sony Official website at: https://www.sony.com).This raises some interesting questions as follows:

- Do the collaboration and partnerships in the networks are equally and fairly beneficial for both parties? Are they willing to share their expertise (core competencies) with each other? Can this collaboration be extended to form partnerships with others in the network?
- Are they developing the standards? If not why? What is the impact of this?

- Are they managing continuous improvement across the network? How do they manage it?

- Do they recognise leadership across the network and not just from one company? How do they manage it?

All of the above discussion suggest that the collaborators/partners need to think about how to manage the standards comprising of open technologies standards, codes of practice and standard for control, and to deal with the issues of managing leadership, continuous improvement and partnerships; internally and externally.

\section{Limitation of the Research}

The quality management field has been studied for more than 100 years dating back to the early 1900s when Fredrick W. Taylor is known as the father of Scientific Management, stressed the importance of quality inspection. First, even though a variety of journals and several renowned books in the field of quality management were considered in this study, it may happen that this topic (i.e. Evolution of Quality Management) had also been covered in other journals and conferences. Additionally, there might be studies that we missed, because they investigate similar phenomena but discuss it with different terms.

However, as we have mentioned earlier the focus of the review was to identify the extant literature rather than reviewing and discussing all relevant contributions, as many contributions built upon each other (See Ahire et al. (1995), Martinez et al. (1998), Sousa \& Voss (2002), Schroeder et al. (2005) and Dahlgaard-Park, S.M. (1999, 2011). In conducting the review, our objective was to describe how quality management field has developed and evolved to date, particularly by tracking its focus over time.

Thus, we specifically looked for the key events and research question that were being addressed rather than identifying specific solutions, models and frameworks.

\section{Concluding remarks}

This article has attempted to reflect on the history of quality management through chronology of its establishment over time. The key aim of this research is to describe how quality management field has developed and evolved to date, particularly by tracking its focus over time. We start the research with the question of; How quality management field has developed and evolved to date, particularly by tracking its focus over time?

In so doing, we have identified that quality management literature have evolved through time with their fundamental focus evolving, and as they evolved, the principles, systems, tools and techniques have changed. 
This witnessed by the findings from the literature revealing that in the early evolution of quality management, this period was focused around products (i.e. How can we ensure quality in a product?). Then, in the later period of time, the focus of quality management has moved from product to process (i.e. How can we ensure quality in the process?). Following from there, the focus of quality management shifting to system focus (i.e. How can we ensure quality in the system?). Slowly but gradually, by the later period of time, there seems to be more attention given to people with the system (people spin), in the development of quality journey. So, the focus in this period was about people in an organisation - people focus (i.e. How can we ensure quality in people?).

Today's the current development of quality management is focused on people with an extended view towards networks focus (i.e. How can we ensure quality in people in the network environment?) and the most recent is the smart focus (i.e. How can we ensure quality in people in the smart environment?). Therefore, we would say that as the focus has changed, the principles have also changed and as the principles have changed, the systems, tools and techniques also have changed in quality management field.

This observation is consistent with Dale (1994) and several authors' works such as (Besterfield et al., 2003; Hellsten \& Klefsjo, 2000; Mahadevan, 2010; Mukherjee \& Kachwala, 2009) that organise their subject of study using the approach of 'principles, systems, and tools and techniques'. As a result of this study, we can confirm that there are emerging patterns and trends on how things have developed and evolved around the fundamental 'focus, principles, systems, and tools and techniques', in relation to the evolution of quality management. In summary, this research suggests that one can study the evolution of this field by looking at how the 'focus, principles, systems, and tools and techniques' have evolved over time.

$t$ this will further increase their job satisfaction.

It is very important for practitioners to understand how important satisfaction with work itself is within the context of job satisfaction of employees. With the amount of time we are spending at work it is no doubt that any manager needs to use all the knowledge he or she has to help increase the job satisfaction of employees, this being even more important in service oriented industries.

Further research that we propose is to investigate job satisfaction among "employees" that manage their own apartments through platforms such as AirBnb, and we have to understand that jobs themselves are changing, Turnšek and Ladkin (2017) did extensive work on Airbnb that has hit the hotel sector hard in recent years, and noted that job satisfaction within the sharing economy, or platform economy, has a completely different position, that is why we propose this as an interesting area to conduct research in.

We have to understand that, not even the best managers can be overseeing how their employees treat their custom- ers all the time. Thus, it is even more important that they can rely on their employees to provide the experience of hospitality for customers at every step of the way, since, as is seen by Rangus and Brumen (2016), the importance of tourism is, after all, visible in its huge impact on the local, national and global economies.

\section{Acknowledgement}

We would like to thank Universiti Teknikal Malaysia Melaka (UTeM) and Gebze Technical University (GTU) for the financial support and facilities provided in completing this research. We will welcome any collaboration for this kind of research with an open arm.

\section{Literature}

ANSI/ASQC. (1987). ANSI/ASQC. 1987 Quality Systems Terminology, American National Standard A3-1987. ANSI/ISO/ASQ. (2000). ANSI/ ISO/ ASQ Q90002000, Quality Management Systems-Fundamentals and Vocabulary. Milwaukee: ASQ Quality Press. ANSI/ISO/ASQC. (1994). ANSI/ISO/ASQC A84021994, Quality Management and Quality Assurance-Vocabulary. Milwaukee, Wisconsin: ASQC.

Arter, D. R., \& Russell, J. P. (2009). ISO Lesson Guide 2008: Pocket Guide to ISO 9001:2008. United States of America: American Society for Quality, Quality Press.

Ahire, S. L., Landeros, R., \& Golhar, D. Y. (1995). Total quality management a literature review and an agenda for future research. Productions and operations management, 4(3), 227-306. https://doi.org/10.1111/j.1937-5956.1995.tb00057.x

Albers, A., Gladysz, B., Pinner, T., Butenko, V., \& Stürmlinger, T. (2016). Procedure for defining the system of objectives in the initial phase of an industry 4.0 project focusing on intelligent quality control systems. Procedia Cirp, 52, 262267. https://doi.org/10.1016/j.procir.2016.07.067

ASQ. (2002). The Quality Improvement Handbook. Milwaukee, Wisconsin: ASQ Quality Press.

Bank, J. (2000). The Essence of Total Quality Management (2nd Edition ed.): Prentice Hall.

Batchelor, R. (1994). HENRY FORD Mass Production, Modernism and design. Manchester: Manchester University Press.

Belohav, J. A. (1993). Quality, strategy and competitiveness. California Management Review, 35(3), 55-67. https://doi.org/10.2307/41166743

Berger, H. (2007). Agile development in a bureaucratic arena-A case study experience. International Journal of Information Management 27, 386-396. https://doi.org/10.1016/j.ijinfomgt.2007.08.009

Besterfield, D. H., Besterfield-Michna, C., Besterfield, G. H., Besterfield-Sacre, M., Urdhwareshe, H., \& 
Urdhwareshe, R. (2003). Total Quality Management (Third ed.). India: Pearson Education Inc.

Betz, F. (1998). Managing technological innovation : competitive advantage from change. New York: Son \& Wiley.

Bititci, U., Garengo, P., Dörfler, V., \& Nudurupat, S. (2012). Performance Measurement: Challenges for Tomorrow. InternationalJournal of Management Reviews, 14,305327. https://doi.org/10.1111/j.1468-2370.2011.00318.x

Bititci, U., Garengo, P., Dorfler, V., \& Nudurupati, S. (2008). Performance Measurement; Question for Tomorrow. SIOM Working Paper Series, No. 0001, www. strath.ac.uk/siom. University of Strathclyde, Glasgow, UK. University of Padavo, Padova, Italy. Retrieved from https://strathprints.strath.ac.uk/id/eprint/13954

Bounds, G., Yorks, L., Adams, M., \& Ranney, G. (1994). Beyond Total Quality Management. New York: McGraw-Hill. BSI. (2000). BS EN ISO 9001:2000 Quality Management Systems. Requirements. In: BSI Standards.

Burge, R. C. (2009). The Baldrige Journey. Industrial Engineer 41, 40-44.

Callan, R. J. (1992). The British Standard 5750 - A quality control instrument for the hotel and catering industry - The case of Astley Bank. International Journal of Hospitality Management 11 (4), 359-372. https://doi.org/10.1016/0278-4319(92)90052-W

Castka, P., \& Balzarova, M. A. (2008). The impact of ISO 9000 and ISO 14000 on standardisation of social responsibility - an inside perspective. International Journal of Production Economics, 113, 74-87. https://doi.org/10.1016/j.ijpe.2007.02.048

Castka, P., Prajogo, D., Sohal, A., \& Yeung, A. C. (2015). Understanding firms' selection of their ISO 9000 third-party certifiers. International Journal of Production Economics, 162, 125-133., 162, 125-133. https://doi.org/10.1016/j.ijpe.2015.01.012

Chaniotakis, I. E., \& Lymperopoulos, C. (2009). Service quality effect on satisfaction and word of mouth in the health care industry. Managing Service Quality, 19(2), 229-242. https://doi.org/10.1108/09604520910943206

Chiaromonte, F. (2004). From R\&D to strategic technology management - Evolution and perspectives. Telektronikk, 2, 33-41.

Cho, Y. S., Jung, J. Y., \& Linderman, K. (2017). The QM evolution: Behavioral quality management as a firm's strategic resource. International Journal of Production Economics, 191, 233249. https://doi.org/10.1016/j.ijpe.2017.05.002

Cochran, P. L. (2007). The evolution of corporate social responsibility. Business Horizons 50, 449454. https://doi.org/10.1016/j.bushor.2007.06.004

Crosby, P. B. (1979). Quality is free: the art of making quality certain. New York: United States of America: New American Library.

Crosby, P. B. (1984). Quality without tears: the art of hassle-free management. New York:
United States of America.: McGraw-Hill. Da Fonseca L.M.C.M. (2015 ). ISO 14001: 2015: An improved tool for sustainability. Journal of Industrial Engineering and Management, 8(1), 37-50. http://dx.doi.org/10.3926/jiem.1298

Dahlgaard-Park, S. M. (1999). The evolution patterns of quality management. Total Quality Management, 10(5), 465-472. https://doi.org/10.1080/0954412997424

Dahlgaard-Park, S. M. (2011). The quality movement: Where are you going? Total Quality Management \& Business Excellence, 22(5), 493-516. https://doi.org/10.1080/14783363.2011.578481

Dahlgaard, J. J., Kristensen, K., \& Kanji, G. K. (2002). Fundamentals of Total Quality Management. Cheltenham: United Kingdom: Nelson Thornes Ltd.

Dahlgaard, S. M. P., \& Dahlgaard, J. J. (2003). Management Control Theories and The European Excellence Model. The Best of Quality, 14.

Dale, B. G. (1994). A Framework for the Introduction of a Process of Quality Improvement in Retail Organizations. International Journal of Retail \& Distribution Management, 22(8), 25-32. https://doi.org/10.1108/09590559410074886

Dale, B. G. (2003). Managing Quality (Fourth ed.). Oxford, UK: Blackwell Publishing Ltd.

Davenport, T. H., \& Prusak, L. (2003). What's the Big Idea? Boston, Massachusetts: Harvard Business School Press.

Dean, J. W. J., \& Bowen, D. E. (1994). Management theory and total quality: Improving research and practice through theory development. The Academy of Management Review, 19(3), 392-418. https://doi.org/10.5465/amr.1994.9412271803

Deming, W. E. (1993). The New Economics For Industry, Government, and Education. Cambridge: Massachusetts Institute of Technology Center for Advanced Engineering Study. Denyer, D., \& Tranfield, D. (2008). Producing a systematic review. In D. e. Buchanan (Ed.), The Sage Handbook of Organizational Research Methods (pp. 671-689). London: Sage.

Devadasan, S. R., \& Goshteeswaran, S. (2005). Design for quality in agile manufacturing environment through modified orthogonal array-basedexperimentation. Journal of Manufacturing Technology Management, 16(6), 576-597. https://doi.org/10.1108/17410380510609456

Document, U. N. (1987). World Commision on Environment and Development: Our Common Future. Retrieved from http://www.un-documents.net/a42r187.htm

Drucker, P. F. (1989). The new realities: in government and politics, in economy and business, in society, and in worldview. Oxford: Heinemann Professional Publishing Limited.

Eckes, G. (2005). Six Sigma Execution: How the World's Greatest Companies Live and Breathe Six Sigma. New York: United States of America: McGraw-Hill. Feigenbaum, A. V. (1961). Total quality control: en- 
gineering and management: the technical and management field for improving product quality, including its reliability, and for reducing operating costs and losses. New York: McGraw-Hill.

Fernie, J., \& Sparks, L. (2014). Logistics and Retail Management: Emerging Issues and New Challenges in the Retail Supply Chain: Kogan Page Publishers.

Foidl, H., \& Felderer, M. (2015). Research challenges of industry 4.0 for quality management. Paper presented at the International Conference on Enterprise Resource Planning Systems. https://doi.org/10.1007/978-3-319-32799-0_10

Ford, H. (1922). My Life and Work. Salt Lake City: UT Project Gutenberg.

Foster, S. T. (2001). Managing Quality an Integrative Approach. New Jersey:United States ofAmerica:PrenticeHall.

Freeman, C., \& Louca, F. (2001). As Time Goes By: From the Industrial Revolutions to the Information Resolution. New York, United States: Oxford University Press.

Garrity, R. B. (1993). Total quality management: an opportunity for high performance in federal organizations. Public Administration Quarterly, 17, 430-459.

Garvin, D. A. (1988). Managing Quality the Strategic and Competitive Edge. New York: The Free Press.

Giannakis, M. (2007). Performance measurement of supplier relationships. Supply Chain Management: An International Journal, 12(6), 400411. https://doi.org/10.1108/13598540710826335

Godfrey, G., Dale, B., Marchington, M., \& Wilkinson, A. (1997). Control: A contested concept in TQM research International Journal Operations \& Production Management, 17(6), 558-573.

Gower,D.L.(Ed.)(1990). Gower HandbookofQualityManagement. England: Gower Publishing Company Limited.

Grant, R. M. (2008). The Future of Management: Where is Gary Hamel Leading Us? Long Range Planning 41, 469-482. https://doi.org/10.1016/j.lrp.2008.06.003

Gunasekaran, A. (1999). Agile manufacturing: A framework for research and development. International Journal Production Economics, 62, 87-105. https://doi.org/10.1016/S0925-5273(98)00222-9

Hakes, C. (1999). The Business Excellent Handbook (5 ed.): BQC Performance Management Limited.

Hamel, G. (2007). The future of management. Boston: Harvard Business School Press.

Hanna, J. (2007). Bringing ,Lean' Principles to Service Industries. Harvard Business School: Research and Ideas, pp. 1-2.

Hellsten, U., \& Klefsjo, B. (2000). TQM as a management system consisting of values, techniques and tools. The TQM Magazine, 12(4), 238-244. https://doi.org/10.1108/09544780010325822

Hill, Y., MacGregor, J., \& Dewar, K. (1996). Nurses' access to higher education: a quality product. Quality Assurance in Education, 4 (2), 2127. https://doi.org/10.1108/09684889610116021
International Automotive Task Force, IATF Guidance to ISO/TS 16949:2002, (2002).

Imai, M. (1986). Kaizen (Ky'zen), the key to Japan's competitive success (1 ed.). New York: McGraw-Hill.

Ishikawa, K. (1985). What is total quality control? The Japaneseway(D.J.Lu,Trans.). New Jersey.:PrenticeHall,Inc.

Jacob, D. (2017). Quality 4.0 Impact and Strategy Handbook. Getting Digitally Connected to Transform Quality Management. .United State of America: LNS Research.

Jayaram, J., Vickery, S., \& Droge, C. (2008). Relationship building, lean strategy and firm performance: an exploratory study in the automotive supplier industry. International Journal of Production Research, 46(20), 56335649. https://doi.org/10.1080/00207540701429942

Jin-Hai, L. (2003). The evolution of agile manufacturing. Business Process Management Journal, 9(2), 170189. https://doi.org/10.1108/14637150310468380

Juran, J. M. (1951). Quality-control handbook. New York: McGraw-hill.

Juran, J. M. (1988). Juran's quality control handbook (4 ed.). New York: McGraw-Hill.

Kanji, G. (2002). Measuring Business Excellence. London.: Routledge.

Kanji, G. K. (1990). Total quality management: the second industrial revolution. Total Quality Management, 1(1), 3-11. https://doi.org/10.1080/09544129000000001

Kano, N. (1993). A perspective on quality activities in American firms. California Management Review, 35(3), 12-31. https://doi.org/10.2307/41166741

Kenney, M., \& Pon, B. (2011). Structuring the smartphone industry: is the mobile internet OS platform the key?. . Journal of Industry, Competition and Trade, 11(3), 239-261. http://dx.doi.org/10.2139/ssrn.1851686

Kremer, R., \& Fabrizio, T. (2005). The Lean Primer - Solutions for the Job Shop. United State: MSC Media, Inc.

Kuei, C.-H., \& Madu, C. N. (2003). Customer-centric six sigma quality and reliability management. International Journal of Quality \& Realibility Management, 20(8), 954-964. https://doi.org/10.1108/02656710310493661

Kumar, M., Kee, F. T., \& Charles, V. (2010). Comparative evaluation of critical factors in delivering service quality of banks: an application of dominance analysis in modified SERVQUAL model. International Journal of Quality and Reliability Management, 27(3), 351-377. https://doi.org/10.1108/02656711011023320

Lee, J., Kao, H. A., \& Yang, S. (2014). Service innovation and smart analytics for industry 4.0 and big data environment. . Procedia Cirp, 16, 3-8. https://doi.org/10.1016/j.procir.2014.02.001

Louis, R. S. (1997). Integrating Kanban with MRP II: Automating a Pull System for Enhanced JIT Inventory Management. Portland, United States of America: Productivity Press.

Macdonald, J. (1995). TQM-does it always works? Some reasons for disappointment In G. K. Kanji (Ed.), Total Quality Management: Proceedings of 
the First World Congress. London: Chapman \& Hall. Macpherson, A., \& Jones, O. (2010). Strategies for the development of International Journal of Management Reviews. International Journal of Management Reviews, 282, 107-113. https://doi.org/10.1111/j.1468-2370.2010.00282.x Mahadevan, B. (2010). Operations Management (Second ed.). New Delhi, India: Pearson Education in South Asia. Malone, T. W. (2004). The future of work: How the new order of business will shape your organization, your management style, and your life. Boston: Harvard Business School Press. Martinez-Lorente, A. R., Dewhurst, F., \& Dale, B. G. (1998). Total quality management: origins and evolution of the term. The TQM Magazine, 10(5), 378386. https://doi.org/10.1108/09544789810231261

Mason, D. (1997). Achieving Investors in People. London: Pitman Publishing. McMenamin, E. (2016). Medical devices: ISO 13485 places new emphasis on risk management. Quality, 55(10), 18-20.

Milakovich, M. M. (1991). Total quality management in the public sector. National Productivity Review, 10, 195-213. https://doi.org/10.1002/npr.4040100208

Miles, M. (1999). Cowboy Quality. Quality Progress, 32(10), 27-34.

Morris, A. S. (2004). ISO 14000 Environmental Management Standards: Engineering and Financial Aspects. Chichester, England: John Wiley \& Sons Limited. https://doi.org/10.1002/0470090782.ch1

Mortimer, S. T., \& Mortimer, D. (2015). Quality and Risk Management in the IVF Laboratory. In. https://doi.org/10.1017/CBO9780511547287.061

Mukherjee, P. N., \& Kachwala, T. T. (2009). Operations Management and Productivity Techniques. New Delhi, India: PHI Learning Private Limited.

Muzaimi, H., Chew, B. C., \& Hamid, S. R. (2017). Integrated management system: The integration of ISO 9001, ISO 14001, OHSAS 18001 and ISO 31000. Paper presented at the AIP Conference Proceedings.

Nakajima, S. (1988). Introduction to TPM: Total Productive Maintenance. Cambridge, London: Productivity Press Incorporations.

Nikkan Kogyo Shimbun, L. f. m. (1988). Poka-yoke: Improving product quality by preventing defects Cambridge: Productivity Press.

Oaklan, J. S. (2014). Total Quality Management and Operational Excellence. New York,: Routledge.

Patty, R. M., \& Denton, M. A. (2010). The End of Project Overruns: Lean and Beyond for Engineering, Procurement and Construction. Florida, United State: Universal-Publishers.

Perakakis, E. (2017). Smart Enough for the Web? A Responsive Web Design Approach to Enhancing the User Web Browsing Experience on Smart TVs. IEEE TRANSACTIONS ONHUMAN-MACHINE SYSTEMS, 47(6), 860-
872. https://doi.org/10.1109/THMS.2017.2726821 Phaal, R., Farrukh, C. J. P., \& Probert, D. R. (2004). A framework for supporting the management of technological knowledge. International Journal Technology Management, 27(1), 1-15. https://doi.org/10.1504/IJTM.2004.003878

Porter, M. E., \& Heppelmann, J. E. (2015). How smart, connected products are transforming companies. . Harvard Business Review, 93(10), 96-114.

Powell, C. T. (1995). Total Quality Management as Competitive Advantage: A Review and Empirical Study. Strategic Management Journal, 16(1), 15-37. https://doi.org/10.1002/smj.4250160105

Prajogo, D. I., \& Sohal, A. S. (2006). The integration of TQM and technology/R\&D management in determining quality and innovation performance. OMEGA, The International Journal of Management Science, 34, 296 - 312. https://doi.org/10.1016/j.omega.2004.11.004 Price, F. (1990). The Quality Concept and Objectives in Gower Handbook of Quality Management. In D. Lock (Ed.), Gower Handbook of Quality Management. Aldershot, England: Gower Publishing Company.

Prusak, L., \& Davenport, T. (2003). Who are the gurus' gurus. Harvard Business Review, 81, 14-16.

Richardson, T. L. (1997). Total Quality Management. New York: United States of America: Delmar Publishers.

Roblek, V., Meško, M., \& Krapež, A. (2016). A complex view of industry 4.0. . SAGE Open, 6(2). https://doi.org/10.1177/2158244016653987

Ross, J. E. (2017). Total Quality MANAGEMENT Text, Cases and Readings. London: Taylor \& Francis Group.

Roth, A. V. (1996). Neo-Operations Strategy: Linking capabilities-Based Competition to Technology. In G. H. Gaynor (Ed.), Handbook of Technology Management. New York: McGraw-Hill.

Rousseau,D.M.,Manning,J.,\&Denyer,D.(2008).Evidence in management and organizational science: Assembling the field's full weight of scientific knowledge through syntheses. The Academy of Management Annals, 2(1), 475-515. https://doi.org/10.1080/19416520802211651

Sanders, A., Elangeswaran, C., \& Wulfsberg, J. P. (2016). Industry 4.0 implies lean manufacturing: Research activities in industry 4.0 function as enablers for lean manufacturing. . Journal of Industrial Engineering and Management (JIEM), 9(3), 811-833. http://dx.doi.org/10.3926/jiem.1940

Schroeder, R. G., Linderman, K., \& Zhang, D. (2005). Evolution of Quality: First Fifty Issues of Production and Operations Management. Production and Operations Management Society, 14(4), 468-481. https://doi.org/10.1111/j.1937-5956.2005.tb00234.x

Shingo, S. (1985). A revolution in manufacturing: the SMED system. Stamford: Productivity Press.

Slack, N., Chambers, S., Johnston, R., \& Betts, A. (2006). Operations and process management: Principles and practice for strategic impact. Har- 
low, England: Prentice Hall Financial Times. Sousa, R., \& Voss, C. A. (2002). Quality management re-visited: a reflective review and agenda for future research. Journal of Operations Management, 20, 91109. https://doi.org/10.1016/S0272-6963(01)00088-2

Stamatis, D. H. (1996). Integrating QS-9000 with your Automotive Quality System. Malaysia: Golden Books Centre Limited. Stamatis, D. H. (2003). Six Sigma fundamentals: a complete guide to the system, methods and tools. New York, United State: Productivity Press.

Tan, L.-H., Hamid, S.-R., \& Chew, B.-C. ( 2016). Service quality audit based on conceptual gaps model of service quality: a case study of top three largest local bank in Malaysia. International Journal Productivity and Quality Management, 18(1), 99115. https://doi.org/10.1504/IJPQM.2016.075712

Tao, F., Cheng, Y., Da Xu, L., Zhang, L., \& Li, B. H. (2014). CCIoT-CMfg: cloud computing and internet of things-based cloud manufacturing service system. . IEEE Transactions on Industrial Informatics, 10(2), 1435-1442. https://doi.org/10.1109/TII.2014.2306383

Tao, F., LaiLi, Y., Xu, L., \& Zhang, L. (2013). FC-PACO-RM: a parallel method for service composition optimal-selection in cloud manufacturing system. IEEE Transactions on Industrial Informatics, 9(4), 2023-2033. https://doi.org/10.1109/TII.2012.2232936

Tao, F., Zhang, L., Venkatesh, V. C., Luo, Y., \& Cheng, Y. (2011). Cloud manufacturing: a computing and service-oriented manufacturing model. Proceedings of the Institution of Mechanical Engineers, Part B: Journal of Engineering Manufacture, 225(10), 19691976. https://doi.org/10.1177/0954405411405575

Taylor, R., \& Pearson, A. (1994). Total Quality Management in Research andDevelopment. The TQMMagazine, 6(1), 26-34. https://doi.org/10.1108/09544789410052723

Thai, V., \& Jie, F. (2018). The impact of total quality management and supply chain integration on firm performance of container shipping companies in Singapore. Asia Pacific Journal of Marketing andLogistics, 30(3), 605-626. https://doi.org/10.1108/APJML-09-2017-0202

TickIT, D. (1992). Department of Trade and Industry/British Computer Society, TickIT making a better job of software. In (2 ed.). London: The Department of Enterprise.

Tranfield, D., Denyer, D., \& Smart, P. (2003). Towards a Methodology for Developing Evidence-Informed Management Knowledge by Means of Systematic Review. British Journal of Management, 14, 207-222. https://doi.org/10.1111/1467-8551.00375

Valerio, B. (2017). Corruption and ISO 37001: A new instrument to prevent it in international entrepreneurship. . World Journal of Accounting, Finance and Engineering, 1, 1-14. https://doi.org/10.21742/wjafe.2017.1.1.01

Vijaykumar, S., Saravanakumar, S. G., \& Balamurugan, M. (2015). Unique sense: Smart computing prototype for industry 4.0 revolution with
IOT and bigdata implementation model. Indian Journal of Science and Technology, 8(35), 1-4. https://doi.org/10.17485/ijst/2015/v8i35/86698 Wang, J., \& Kleiner, B. H. (2005). The Evolution of $\mathrm{R} \& \mathrm{D}$ Management. Management Research News, 28(11/12), 88-95. Watson, R., Wilson, H. N., Smart, P., \& Macdonald, E. K. (2018). Harnessing Difference: A Capability-Based Framework for Stakeholder Engagement in Environmental Innovation PROD INNOV MANAG, 35(2), 254-279. https://doi.org/10.1111/jpim.12394 Womack, J. P., Jones, D. T., \& Roos, D. (1990). The Machine that changed the world: based on Massachusetts Institute of Technology. New York: United States of America: Rawson Associates. Yoon, Y., Giirhan-Canli, Z., \& Schwarz, N. (2006). The Effect Of Corporate Social Responsibility (Csr) Activities On Companies With Bad Reputations. Journal Of Consumer Psychology, 16(4), 377390. https://doi.org/10.1207/s15327663jcp1604_9

Zairi, M. (1994). Measuring Performance for Business Results. London, United Kingdom: Chapman \& Hall.

Zeithaml, V. A., Parasurarnan, A., \& Malhotra, A. (2002). Service Quality Delivery Through Web Sites: A Critical Review of Extant Knowledge. Journal of the Academy of Marketing Science, 30(4), 362-375. https://doi.org/10.1177/009207002236911

Mohd Syaiful Rizal Hamid, is associate professor and a former Dean of the Faculty of Technology Management and Technopreneurship at the Universiti Teknikal Malaysia Melaka, Malaysia (UTeM). He received his Ph.D. in School of Engineering, Design Manufacture Engineering Management from the University of Strathclyde, United Kingdom. His fields of expertise are technology management and quality management and his research focuses on Quality Tools and Techniques, Environmental Management, Service Management \& Sustainable Development.

Saifuddin Isa is a Master of Sciences in the field of Technology Management (Innovation). $\mathrm{He}$ is a researcher at Universiti Teknikal Malaysia Melaka (UTeM), Faculty of Technology Management and Technopreneurship. His research focuses is Quality Tools and Techniques of Industrial Revolution 4.0, particularly in the Smart Manufacturing context. His main area of expertise are Quality Management, Operation Management and Technology Management. 
Chew Boon Cheong is presently the Associate Professor of Faculty of Technology Management and Technopreneurship (FPTT), Universiti Teknikal Malaysia Melaka (UTeM). He received his Ph.D. from University of Edinburgh in 2012 in Technology Management and Science and Technology Studies. His primary research interest is renewable energy development and deployment, clean technology innovation and introduction, green and sustainable practise, human technology innovation and introduction; which all are angled from social science and technology management studies.
Abdullah Altun is a chief specialist in the Informatics and Information Security Research Center (BILGEM) in The Scientific and Technological Research Council of Turkey (TÜBITAK). He has a Ph.D. degree in economics. His primary research interests are international trade and growth economics. His studies are mainly about the empirical analysis of global value chains. He has visited various universities as a visiting scholar such as University of Warsaw (Poland) and Universiti Teknikal Malaysia Melaka, UTeM (Malaysia). 


\section{Appendix}

Table 1 below summarises the quality management literature over time. It should be noted that the 'key events' in Table 1 indicates the important events in Quality Management field over time that considered been seen as were giving a larger scale of impact to the quality management in general.

Table 1: Important events in the quality management movement

\begin{tabular}{|c|c|c|c|}
\hline Key Focus & $\begin{array}{l}\text { App. } \\
\text { Time }\end{array}$ & Key Events & Key References \\
\hline \multirow{10}{*}{$\begin{array}{l}\text { How can we ensure } \\
\text { quality in product? }\end{array}$} & 1900 & $\begin{array}{l}\text { Fredrick W. Taylor calls as the father of } \\
\text { Scientific Management stressed on inspec- } \\
\text { tion activities }\end{array}$ & Garvin (1988); Foster (2001) \\
\hline & $1910 \mathrm{~s}$ & $\begin{array}{l}\text { Henry Ford came out with Model T (be- } \\
\text { came the Ford car) and introduced of mov- } \\
\text { ing assembly line which lead to mass pro- } \\
\text { duction concept (quality interchangeability) }\end{array}$ & Batchelor (1994); Womack, et al., (1990) \\
\hline & $1920 \mathrm{~s}$ & $\begin{array}{l}\text { Walter Shewhart of Bell Laboratories de- } \\
\text { veloped a system for measuring variance } \\
\text { in production system, known as statistical } \\
\text { process control. Shewhart also created the } \\
\text { Plan-Do-Check-Act (PDCA) cycle, which } \\
\text { applies a systematic approach to improving } \\
\text { work processes }\end{array}$ & Garvin (1988) \\
\hline & 1922 & $\begin{array}{l}\text { Inspection activities were linked more for- } \\
\text { mally to quality control with the publication } \\
\text { of G.S Radford's The Control of Quality in } \\
\text { Manufacturing. Quality was viewed as a dis- } \\
\text { tinct management responsibility and as an } \\
\text { independent function }\end{array}$ & Garvin (1988) \\
\hline & 1924 & $\begin{array}{l}\text { Walter Shewhart of Bell Laboratories de- } \\
\text { veloped Statistical Process Control (SPC) }\end{array}$ & American Society for Quality (2002) \\
\hline & 1926 & $\begin{array}{l}\text { The Bell Telephone began to apply statisti- } \\
\text { cal control methods }\end{array}$ & $\begin{array}{l}\text { Martinez-Lorente, Dewhurst and Dale } \\
(1998)\end{array}$ \\
\hline & 1931 & $\begin{array}{l}\text { Shewhart has published Economic Control } \\
\text { of Quality of Manufactured Product, giv- } \\
\text { ing the discipline a scientific footing for the } \\
\text { first time. Shewhart gave a precise and mea- } \\
\text { surable definition of manufacturing control, } \\
\text { developed powerful techniques for monitor- } \\
\text { ing and evaluating day-to-day production, } \\
\text { and suggested a variety of ways of improv- } \\
\text { ing quality }\end{array}$ & $\begin{array}{l}\text { Garvin (1988); American Society for } \\
\text { Quality (2002) }\end{array}$ \\
\hline & 1938 & $\begin{array}{l}\text { Deming published a technical book and } \\
\text { taught courses in the use of his statistical } \\
\text { methods }\end{array}$ & American Society for Quality (2002) \\
\hline & 1939 & $\begin{array}{l}\text { Shewhart wrote Statistical Method from the } \\
\text { viewpoint of Quality Control }\end{array}$ & American Society for Quality (2002) \\
\hline & & $\begin{array}{l}\text { Shewhart's idea for the Plan-Do-Check-Act } \\
\text { cycle was used extensively by Deming and } \\
\text { others to help manage quality improvement } \\
\text { projects }\end{array}$ & $\begin{array}{l}\text { Garvin (1988); American Society for } \\
\text { Quality (2002) }\end{array}$ \\
\hline
\end{tabular}


Table 1: Important events in the quality management movement (continued)

\begin{tabular}{|c|c|c|c|}
\hline & 1940 & $\begin{array}{l}\text { A committee was formed in December by } \\
\text { the American war department to draft stan- } \\
\text { dards in the area quality }\end{array}$ & Garvin (1988) \\
\hline & 1942 & $\begin{array}{l}\text { A quality control section was established in } \\
\text { the war department staff mainly by statisti- } \\
\text { cians from Bell Laboratories. This group de- } \\
\text { veloped a new set of sampling, tables based } \\
\text { on the concept of acceptable quality levels } \\
\text { (AQL) }\end{array}$ & Garvin (1988) \\
\hline & 1943 & $\begin{array}{l}\text { Ishikawa invented Fish-Bone diagram } \\
\text { which bears his name as Ishikawa Diagram } \\
\text { as management problem solving tools }\end{array}$ & Dahlgaard, et al., (2002) \\
\hline & $\begin{array}{l}\text { Mid- } \\
1940 \mathrm{~s}\end{array}$ & $\begin{array}{l}\text { The American army pushed the use of sam- } \\
\text { pling methods during World War II }\end{array}$ & $\begin{array}{l}\text { Martinez-Lorente, Dewhurst and Dale } \\
\text { (1998) }\end{array}$ \\
\hline & 1946 & $\begin{array}{l}\text { Japanese Industrial Standards Committee } \\
\text { is established. Union of Japanese Scientists } \\
\text { and Engineers (JUSE) is established } \\
\text { Deming involved with the Union of Scien- } \\
\text { tists Engineer (JUSE) after its formation }\end{array}$ & $\begin{array}{l}\text { Garvin (1988) } \\
\text { American Society for Quality (2002); } \\
\text { Foster (2001) }\end{array}$ \\
\hline \multirow[t]{2}{*}{$\begin{array}{l}\text { How can we ensure } \\
\text { quality in process? }\end{array}$} & 1950 & $\begin{array}{l}\text { First visit of Deming to Japan. Deming give } \\
\text { a talk and taught Japanese's leaders about } \\
\text { statistical quality control techniques (SQC) } \\
\text { JUSE publishes the magazine Statistical } \\
\text { Quality Control. Japanese Industrial Stan- } \\
\text { dards are established under the Industrial } \\
\text { Standardization Law }\end{array}$ & $\begin{array}{l}\text { Garvin (1988); Foster (2001); Bank } \\
\text { (2000); Martinez-Lorente, Dewhurst and } \\
\text { Dale (1998) }\end{array}$ \\
\hline & $1950 \mathrm{~s}$ & $\begin{array}{l}\text { Failure Mode Effect Analysis (FMEA) } \\
\text { developed by US military after the Korean } \\
\text { war. } \\
\text { Reliability engineering developed by } \\
\text { American Department of Defence which } \\
\text { formed an Ad Hoc Group on Reliability of } \\
\text { Electronic Equipment } \\
\text { The basis of the kaizen revolution in Japan } \\
\text { that took place in the 1950s along with the } \\
\text { used of Kanban, Jidoka and Just in Time } \\
\text { (JIT) together to continually improves pro- } \\
\text { duction processes } \\
\text { Taiichi Ohno, who is generally recognised } \\
\text { as the 'father of JIT' due to his pioneering } \\
\text { work at Toyota in the 1950s and 1960s. } \\
\text { Preventive maintenance was introduced in } \\
\text { the 1950s where in Japan Total Productive } \\
\text { Maintenance (TPM) is called Preventive } \\
\text { Maintenance }\end{array}$ & $\begin{array}{l}\text { Bounds, Yorks, Adams and Ramney } \\
\text { (1994); Gower (1990) } \\
\text { Richardson (1997); Gower (1990); Louis } \\
\text { (1997); Dahlgaard, et al., (2002) } \\
\text { Nakajima (1988); Richardson (1997) }\end{array}$ \\
\hline
\end{tabular}


Table 1: Important events in the quality management movement (continued)

\begin{tabular}{|c|c|c|c|}
\hline & 1951 & $\begin{array}{l}\text { Deming Prize is established in Japan } \\
\text { Juran published his first edition of Quality } \\
\text { Control Handbook }\end{array}$ & $\begin{array}{l}\text { Garvin (1988); Foster (2001); Dahlgaard, } \\
\text { et al., (2002) } \\
\text { Garvin (1988); Bank (2000); American } \\
\text { Society for Quality (2002) }\end{array}$ \\
\hline & 1954 & First visit of Juran to Japan & $\begin{array}{l}\text { Garvin (1988); American Society for } \\
\text { Quality (2002) }\end{array}$ \\
\hline & 1956 & $\begin{array}{l}\text { Armand Feigenbaum introduced total a prin- } \\
\text { cipe called Total Quality Control (TQC) } \\
\text { which underlying principles to provide gen- } \\
\text { uine effectiveness control must start with the } \\
\text { design of the product and end only when the } \\
\text { product has been placed in the hand of the } \\
\text { customer who remain satisfied }\end{array}$ & Garvin (1988); Feigenbaum (1961) \\
\hline \multirow{6}{*}{$\begin{array}{l}\text { How can we ensure } \\
\text { quality in system? }\end{array}$} & $\begin{array}{l}\text { Early } \\
1960 \mathrm{~s}\end{array}$ & $\begin{array}{l}\text { Ishikawa is best known as a pioneer of the } \\
\text { "quality circle" movement in Japan }\end{array}$ & American Society for Quality (2002) \\
\hline & $1960 \mathrm{~s}$ & $\begin{array}{l}\text { Crosby invented the concept of Zero De- } \\
\text { fects Goals in the } 1960 \text { s. } \\
\text { Crosby lists for new essentials of quality } \\
\text { management which he calls "The Abso- } \\
\text { lutes" }\end{array}$ & $\begin{array}{l}\text { Crosby (1979); Garvin (1988); American } \\
\text { Society for Quality (2002); Bank (2000) }\end{array}$ \\
\hline & 1961 & $\begin{array}{l}\text { First edition of Feigenbaum's Total Qual- } \\
\text { ity Control }\end{array}$ & $\begin{array}{l}\text { Martinez-Lorente, Dewhurst and Dale } \\
\text { (1998) }\end{array}$ \\
\hline & 1962 & $\begin{array}{l}\text { Ishikawa's quality circles where first pilot- } \\
\text { ed at Nippon Telegraph and cable compa- } \\
\text { ny. Published a book named What Is Total } \\
\text { Quality Control } \\
\text { The idea of quality circles appeared in the } \\
\text { first issue of the Japanese journal Quality } \\
\text { Control for the Foreman (Genba-To-QC) }\end{array}$ & $\begin{array}{l}\text { Bank (2000); American Society for } \\
\text { Quality (2002) } \\
\text { Garvin (1988) }\end{array}$ \\
\hline & 1968 & $\begin{array}{l}\text { Ishikawa produced a non-technical quality } \\
\text { analysis textbook for quality circle members } \\
\text { Most large Japanese companies had adopted } \\
\text { what Ishikawa called Companywide Qual- } \\
\text { ity Control (CWQC) in Japan to produce } \\
\text { world-class quality products }\end{array}$ & American Society for Quality (2002) \\
\hline & $\begin{array}{l}\text { Early } \\
1970 \text { s }\end{array}$ & $\begin{array}{l}\text { Taguchi developed the concept of the Qual- } \\
\text { ity Loss Function. } \\
\text { The method provides an efficient technique } \\
\text { to design product tests prior to entering the } \\
\text { manufacturing phase }\end{array}$ & American Society for Quality (2002) \\
\hline
\end{tabular}


Table 1: Important events in the quality management movement (continued)

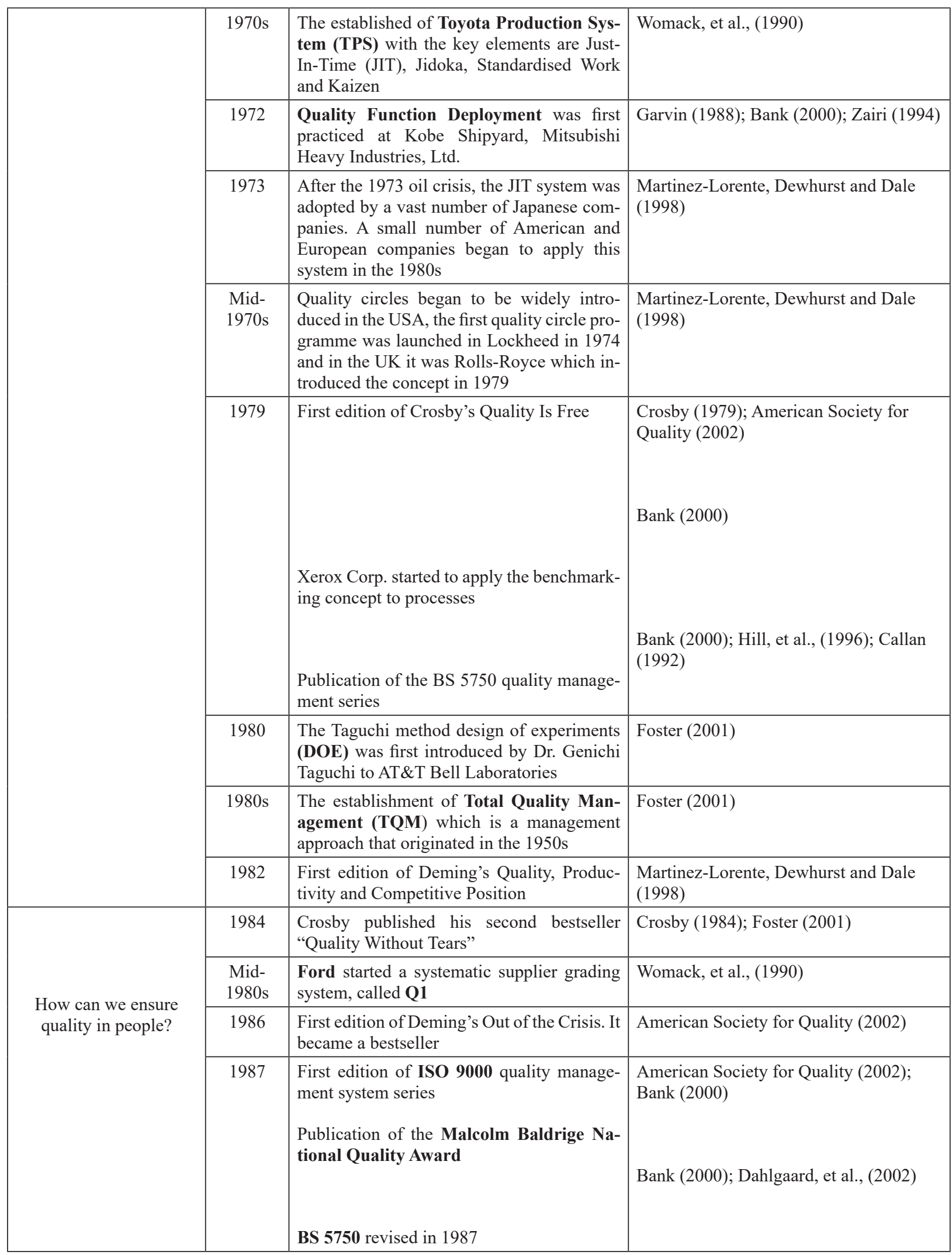


Table 1: Important events in the quality management movement (continued)

\begin{tabular}{|c|c|c|c|}
\hline & $1990 \mathrm{~s}$ & $\begin{array}{l}\text { Xerox introduced leadership through quality } \\
\text { as a vehicle for change. } \\
\text { Six Sigma was developed at Motorola. } \\
\text { Lean Manufacturing derives from the Toy- } \\
\text { ota Production System or Just in Time Pro- } \\
\text { duction. } \\
\text { The "lean manufacturing" concept was pop- } \\
\text { ularized in American factories in large part } \\
\text { by the Massachusetts Institute of Technolo- } \\
\text { gy study of the movement from mass pro- } \\
\text { duction toward production as described in } \\
\text { The Machine That Changed the World: } \\
\text { The Story Of Lean Production. }\end{array}$ & $\begin{array}{l}\text { Garvin (1988) } \\
\text { Eckes (2005, p. 12) } \\
\text { Womack, et al., (1990) }\end{array}$ \\
\hline & 1991 & $\begin{array}{l}\text { National Training Task Force introduced In- } \\
\text { vestors in People (IIP) in October } 1991\end{array}$ & Mason (1997) \\
\hline & 1992 & $\begin{array}{l}\text { The EFQM Excellence Model was intro- } \\
\text { duced at the beginning of } 1992 \text { as the frame- } \\
\text { work for assessing organisations for the Eu- } \\
\text { ropean Quality Award }\end{array}$ & Dahlgaard, et al., (2002) \\
\hline & 1994 & $\begin{array}{l}\text { QS } 9000 \text { is developed by Daimler-Chrysler, } \\
\text { Ford \& General Motor where it is based on } \\
\text { ISO 9001: } 1994 \text {. } \\
\text { The system became effective on September } \\
\text { 1, } 1994\end{array}$ & Stamis (1996) \\
\hline \multirow{6}{*}{$\begin{array}{l}\text { How can we ensure } \\
\text { quality in people in the } \\
\text { network environment? }\end{array}$} & \multirow[t]{2}{*}{1996} & $\begin{array}{l}\text { First edition of ISO } 14000 \text { environmental } \\
\text { management series }\end{array}$ & $\begin{array}{l}\text { International Organisation for Standardi- } \\
\text { sation at www.iso.org; Moris (2004) }\end{array}$ \\
\hline & & $\begin{array}{l}\text { First edition of OHSAS } \mathbf{1 8 0 0 0} \text { - occupa- } \\
\text { tional health and safety management series, } \\
\text { which derived from the British Standard } \\
\text { BS8800:1996 }\end{array}$ & $\begin{array}{l}\text { International Occupational Health } \\
\text { and Safety Management at } \\
\text { www.ohsas-18001-occupation- } \\
\text { al-health-and-safety.com; British Stan- } \\
\text { dards Institute at www.bsigroup.com }\end{array}$ \\
\hline & 1998 & QS 9000 reissued in March 1998 & Stamatis (1996) \\
\hline & $\begin{array}{l}\text { Early } \\
2000\end{array}$ & $\begin{array}{l}\text { TickIT originally set up by UK Department } \\
\text { of Trade and Industry and administered by } \\
\text { British Standards Institution (BSI), which } \\
\text { applies to all types of information system } \\
\text { supply, which involve software develop- } \\
\text { ment processes }\end{array}$ & TickIT (1992) \\
\hline & 2000 & $\begin{array}{l}\text { The } 2000 \text { edition of the ISO } 9000 \text { was es- } \\
\text { tablished }\end{array}$ & American Society for Quality (2002) \\
\hline & 2002 & $\begin{array}{l}\text { International Automotive Task Force } \\
\text { (IATF) - automakers General Motor, Chrys- } \\
\text { ler and Ford developed ISO/TS 16949:2002 }\end{array}$ & $\begin{array}{l}\text { International Automotive Task Force } \\
\text { (IATF) (2002) }\end{array}$ \\
\hline
\end{tabular}


Table 1: Important events in the quality management movement (continued)

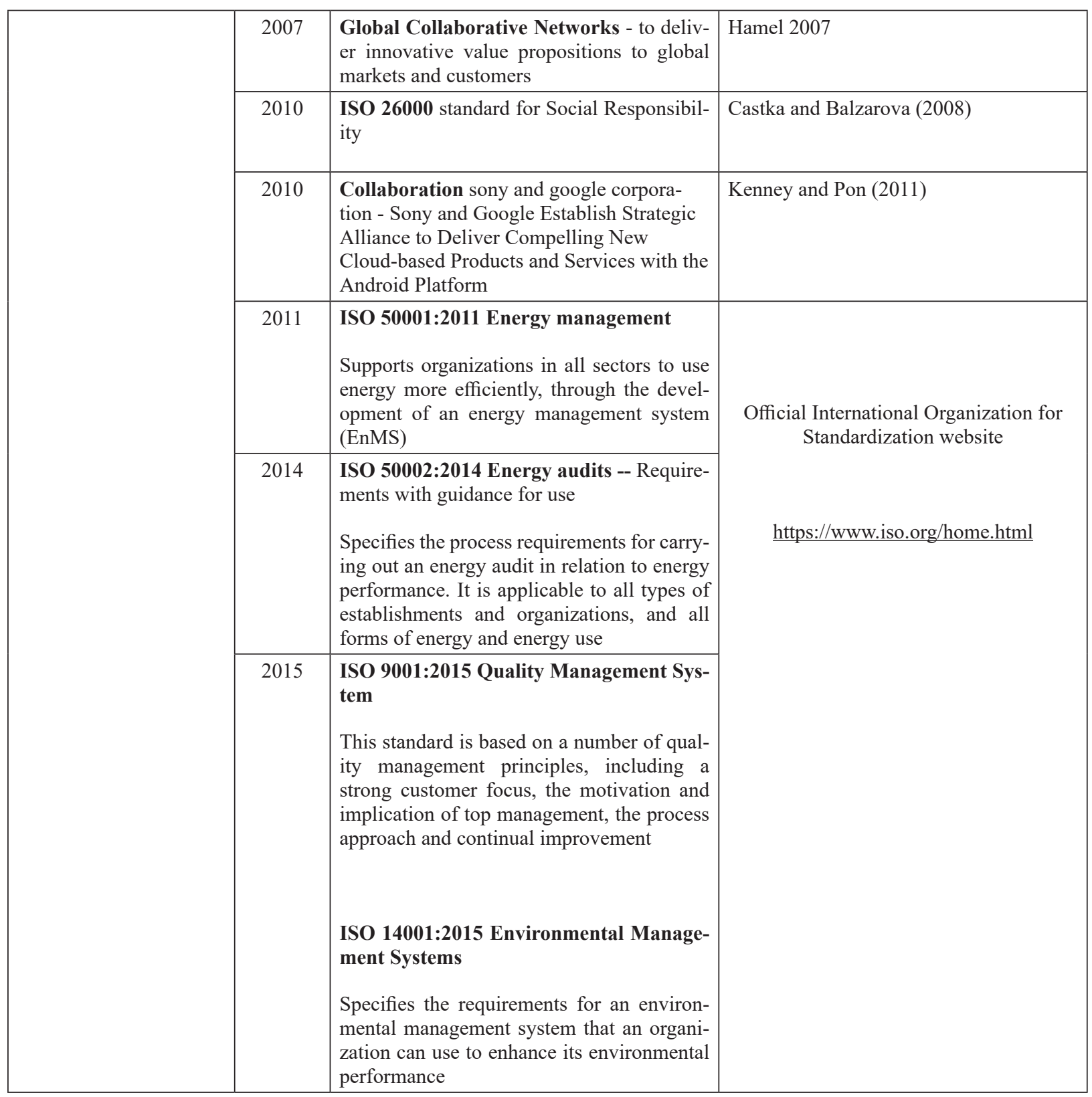


Table 1: Important events in the quality management movement (continued)

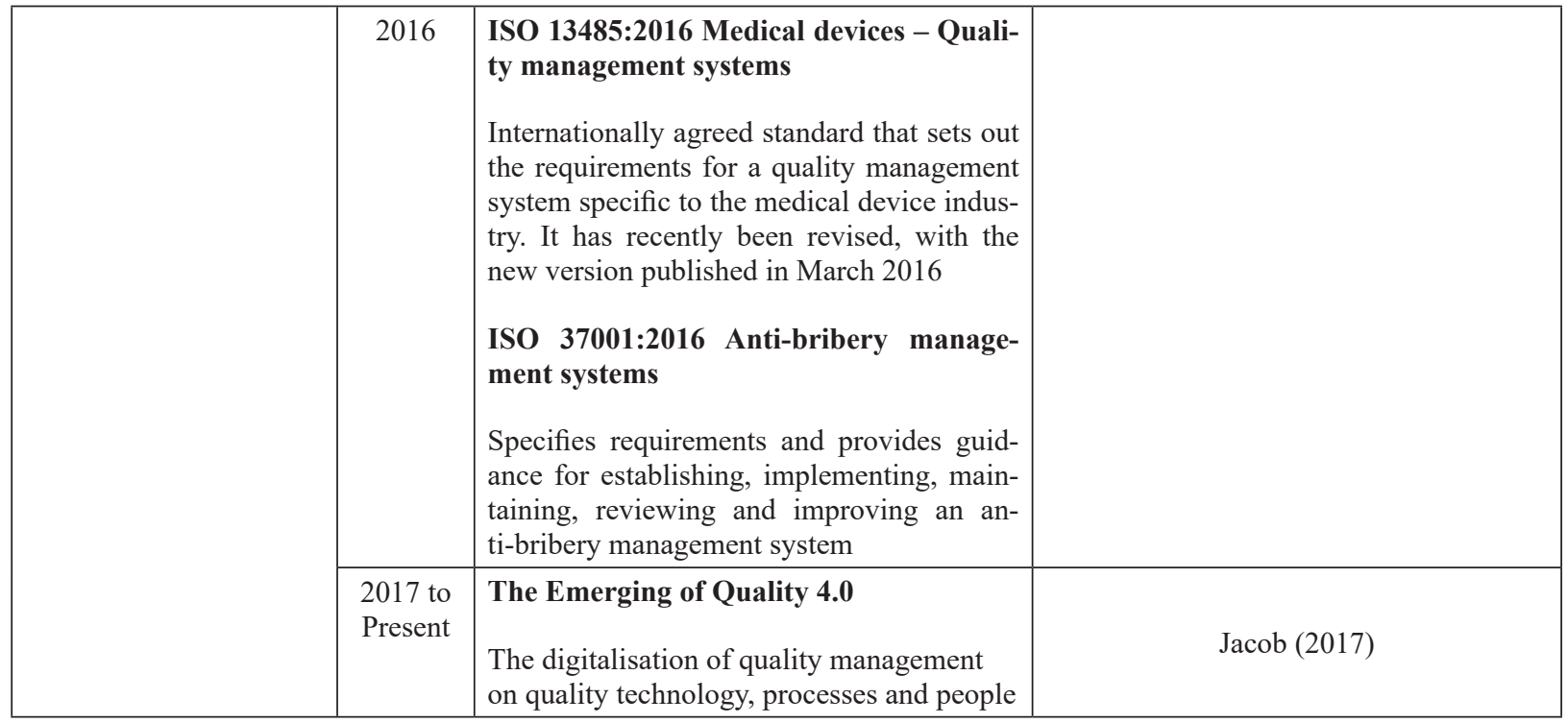

